\title{
A LOCALIST CRITIQUE OF THE NEW FEDERALISM
}

\author{
DAVID J. BARRON $\dagger$
}

\section{INTRODUCTION}

This Essay takes the recent federalism revival ${ }^{1}$ to rest, at least in part, on a commitment to a more localized form of decisionmaking. The notion that more governmental decisions could and should be handled locally seems to fit with the times. There is increasing philosophical skepticism about the existence of "right" answers, more comfort with the notion that democracy depends upon reasonable disagreement, and growing uneasiness with top-down solutions that threaten to entrench inefficiencies and squelch innovation. There also is an undeniable appeal to the contention that community-level responses often have been the more creative ones of late. Even corporate bureaucracies now see the virtues of decentralization. The Supreme Court's new federalism, in this respect, is of a piece with a more thoroughgoing aversion to centralization and corresponding attraction to local decisionmaking. These localist instincts seem to be defensible, even reasonable. Perhaps, even, progressive.

This Essay nevertheless argues that those who are attracted to this localist orientation should be wary of the recent federalism revival. This revival focuses on protecting the autonomy of state and local governments by limiting the power of the central government. The invocation of "local autonomy" conjures up the attractive values as-

Copyright $(0) 2001$ by David J. Barron.

$\dagger$ Assistant Professor of Law, Harvard Law School. This Essay is a response to papers presented at the Constitution in Exile conference hosted by the Program in Public Law at Duke University School of Law on October 5-7, 2000. I wish to thank Sam Bagenstos, Jerome Barron, Myra Barron, Chris Desan, Dick Fallon, Jerry Frug, Daniel Halberstam, Elena Kagan, Jeff Kehne, David Kennedy, Dan Meltzer, Frank Michelman, Charles Sabel, and Phil Weiser for extremely helpful comments. I also wish to thank the Duke Program in Public Law, and in particular Chris Schroeder, for hosting an excellent conference.

1. See infra Part III.B. 
sociated with protecting localized decisionmaking: promoting responsive and participatory government by bringing the government closer to the people; fostering diversity and experimentation by increasing the fora for expressing policy choices and creating a competition for a mobile citizenry; and providing a check against tyranny by diffusing power that would otherwise be concentrated. These values are powerful ones. To trump them, the defender of central power traditionally must show that the issue is really one of central, rather than local, concern. Against the values of decentralization, the defender of central power must assert the virtues of centralization: the uniformity it provides; the superior expertise, talent, or deliberative capacity that it exhibits by drawing decisionmakers from a broader populace; the aggregate social welfare it promotes by requiring that costs of local action be internalized; or the central values that will be vindicated by overcoming the dangers of faction and parochialism. ${ }^{2}$

The current federalism revival's invocation of local autonomy thus appears to vindicate the values associated with decentralization that make a localist orientation attractive. And it thus would seem that challenges to the federalism revival must rest on appeals to the ways that centralized power can overcome the pathologies of local decisionmaking. In this way, the current federalism revival draws strength from the current skepticism towards centralization-with the specter of big government and the constraints that it raises-and the current ascendancy of decentralization, with the prospect of selfgovernment and freedom that it offers.

But local autonomy is a more complex concept than we often acknowledge. ${ }^{3}$ Before we accept the suggestion that protecting local autonomy from central power promotes localist values, it is important to attend to the absence of a clear baseline in defining what local autonomy means. ${ }^{4}$ The baseline problem arises because no city or state is an island jurisdiction. The ability of each locality to make ef-

2. For surveys of these and other arguments for and against decentralized decisionmaking in a federal system, see generally David L. SHAPIRO, FederalisM: A DiAlogue 107-40 (1995); Steven G. Calabresi, “A Government of Limited and Enumerated Power”: In Defense of United States v. Lopez, 94 MiCH. L. REV. 752, 774-84 (1995).

3. I use the term "local autonomy" to encompass both state and local governmental autonomy.

4. The notion of baselines, and its attendant problems, has been addressed in other contexts. For example, Professor Sunstein discusses and criticizes the use of common law rules as neutral baselines in connection with individual constitutional rights challenges to legislation. Cass R. Sunstein, Lochner's Legacy, 87 COLUM. L. REV. 873, 874-75 (1987). 
fective decisions on its own is inevitably shaped by its relation to other cities and states, by its relation to broader, private market forces, and, most importantly, by the way the central power structures these relations, even when central governmental power appears to be dormant. Because the local sphere is part and parcel of a larger coordinated system of local jurisdictions that is structured by less visible background central-law rules, central power is often deeply (if not visibly) implicated in what we understand local autonomy to mean. Once one attends to this point, it becomes clear that a single-minded desire to protect local autonomy by limiting central power actually may do little to promote the values normally associated with local autonomy. ${ }^{5}$

To the extent the Court's current attempt to protect local autonomy is intended to promote the values associated with decentralized decisionmaking, ${ }^{6}$ it errs in overlooking the baseline problem. It too often takes the current amount of discretion that central law affords local governments to be the baseline against which claimed central governmental infringements of local autonomy are measured. By viewing the existing, centrally established structure as a "neutral"

5. In assessing how law can protect the autonomy of individuals, rather than governmental entities, it is clear that much depends on what one takes autonomy to mean. For example, one can distinguish between autonomy as negative liberty, in which the emphasis is on freeing individuals from governmentally imposed restraints, and autonomy as positive liberty, in which the emphasis is on empowering individuals through governmentally provided assistance. See Richard H. Fallon, Jr., Two Senses of Autonomy, 46 STAN. L. ReV. 875, 880-85 (1994) (contrasting negative and positive libertarian conceptions of descriptive autonomy). Cross-cutting these notions of autonomy are two other senses of autonomy: ascriptive autonomy and descriptive autonomy. The former emphasizes the autonomy that one is entitled to exercise by virtue of being an individual, and thus conceives of autonomy in metaphysical terms that make it meaningless to assess how autonomous a person is in fact. Id. at 890-93. The latter conceives of autonomy as an "empirical condition or capacity or an ideal for human life," and thus makes it meaningful to assess how autonomous specific persons are in fact. Id. at $879-80$. The precise connection between the vocabulary developed for thinking about the autonomy of individuals and the effort to untangle what should count as autonomy for governmental entities in a federal system is not at all clear. Governments are not just like private individuals and thus there is no reason to assume that well-developed notions of individual autonomy are appropriately deployed in thinking about the autonomy of governmental entities. Referencing the contestability of the concept of autonomy in connection with the rights of individuals, however, does point to the contestability of the concept of autonomy in thinking about the rights of states and local governments in a federal system.

6. It is, of course, possible that this is not the point of these decisions at all. Their point simply may be to implement faithfully the Founders' intent in establishing states or to respect the constitutional text's enumeration of federal powers and the Tenth Amendment, even though such faithful implementation may produce none of the benefits that are associated with the localist orientation described above. It is only insofar as the decisions seem normatively attractive because of their association with that localist orientation that this critique applies. 
baseline that protects local autonomy, the Court fails to consider how that structure itself acts as a constraint on local autonomy. As a consequence, it does not consider the possibility that changes in central law actually may be shifting the relative autonomy of localities, vis-àvis each other, rather than limiting local autonomy across the board. Nor does the Court consider that the allegedly infringing central law, by altering the background framework within which local power is exercised, may be creating new opportunities for exercising local power that were not available under the old centrally established framework. So, for example, the Court recently has held that, in the name of protecting local autonomy, the federal government is prohibited from commandeering a local government. ${ }^{7}$ The Court does not contemplate, however, that such commands may promote local autonomy by altering the background legal structure in a way that protects local governments from the costs that the current, centrally established legal framework permits local governments to impose upon their neighbors. In other words, the Court ignores-wrongly, I argue-both the ways the preexisting centrally created legal regime may be limiting local autonomy and the ways a new, seemingly less protective centrally established legal regime actually might enhance it.

Inattention to the baseline problem also occurs outside the sphere of constitutional doctrine. The force of the intuitive claim that central law is a constraint on, rather than a component of, local autonomy $^{8}$ threatens to tag many important recent reform proposals with a "big government" label they do not deserve. Because such proposals call for the significant exercise of central power, ${ }^{9}$ they are

7. Printz v. United States, 521 U.S. 898, 933 (1997).

8. See, e.g., U.S. ADVISORY COMM'N ON INTERGOVERNMENTAL RELATIONS, STATE LAws GOVERNING LOCAL GOVERNMENT STRUCTURE AND AdMINISTRATION 1-5 (1993) (treating central intervention as a threat to local autonomy); Gordon L. Clark, $A$ Theory of Local Autonomy, 74 ANNALS Ass'N AM. GEOGRAPHERs 195, 199-203 (1984) (promoting a theory of local autonomy based on immunity from higher state authority and legislative initiative reposed in local residents).

9. See Gerald E. Frug, City Making: Building Communities Without Building WALLS 86-88 (1999) (discussing the virtues of a regional legislature charged with negotiating the entitlements to be held by local governments); Michael C. Dorf \& Charles F. Sabel, A Constitution of Democratic Experimentalism, 98 COLUM. L. REV. 267, 316-23 (1998) (suggesting ways of reconceiving the central and local governmental relationship in which local discretion is enhanced even as national monitoring and supervision is rendered more intensive); $c f$. Clayton P. Gillette, Regionalization and Interlocal Bargains, 76 N.Y.U. L. REV. 190, 195 (2001) (discussing the role that background rules of state law play in frustrating and inducing interlocal bargains). 
seen as a threat to local autonomy, implicating the familiar clash between the benefits of decentralized decisionmaking on the one hand, and the benefits of centralized decisionmaking on the other. ${ }^{10}$ Once one acknowledges the more complicated relationship between local autonomy and central power, however, these proposals are better understood as efforts to alter the central frameworks within which local discretion is inevitably exercised, rather than as attempts to substitute centralized command for local control. From this perspective, such proposals are no more threats to local control than the less visible, centrally imposed frameworks they would replace.

To pursue this argument, this Essay examines not only the law of federalism, which defines the relations of the federal government visà-vis state and local governments, but also the law of localism, which defines the relations between states and their local governments. There are some natural points of connection between these two bodies of law. Federalism decisions often involve local, rather than state, governmental parties; indeed, the decisions are often unclear as to whether it is a commitment to the free exercise of local, rather than state, power that drives them. And to the extent that the federalism revival is motivated by a desire to protect local control, it is critical to think about how law protects local control within states, and not simply state control as against the federal government. Many of the most important matters of public policy-from crime control to education to land-use planning - are resolved to an important degree through local, rather than state, governmental decisionmaking.

The law of localism also provides a useful comparative perspective from which to consider the law of federalism. The idea that background provisions of central law powerfully shape the scope of local autonomy is much easier to grasp in the context of state-local relations than it is in federal-state relations. The longstanding notion that local governments are creatures of their states makes it hard to see how local autonomy within states could be meaningfully understood independent of the way that state law chooses to protect it. And once the complications that arise in trying to protect local autonomy within states are seen, it becomes apparent that similar complications arise

10. See, e.g., Gillette, supra note 9, at $197 \mathrm{n} .21$ (equating proposal to establish regional legislature to change background state law rules with the centralization that attends the establishment of a consolidated, regional government); Roderick M. Hills, Jr., Romancing the Town: Why We (Still) Need a Democratic Defense of City Power, 113 HaRV. L. ReV. 2009, 2012 (2000) ("Any expansion of regional power will inherently diminish citizen interaction and voice in local government.”). 
within the law of federalism, notwithstanding the fact that states are not merely creatures of the national government. It then becomes possible to see that central governmental power may be defended at all levels of the constitutional structure in the name of promoting the virtues that attend local governmental decisionmaking. Indeed, it shows that those virtues may even be undermined by a legal system that commits itself-as the Supreme Court now appears to be committed-to seeking out a separate sphere of local autonomy that must be protected from central lawmaking.

Part I sets forth the conceptual framework for the more detailed arguments that follow by specifying what counts as a localist argument for central power, as opposed to an argument for central power that seeks to overcome the pathologies of local decisionmaking. Part II examines the law of localism and the ways state power creates, rather than simply limits, local autonomy. Part III draws on the law of localism to consider the law of federalism. I show how the current law of federalism overlooks the baseline problem in its defense of local autonomy and thus constitutes a poor way of promoting the values associated with localism.

\section{What COUNTS As A LOCALIST ARGUMENT FOR CENTRAL POWER}

There is a value in ensuring that local jurisdictions have the discretion to make the decisions that their residents wish them to make. The value inheres in the traditional advantages that attend decentralization. These include more participatory and responsive government; more diversity of policy experimentation; more flexibility in responding to changing circumstances; and more diffusion of governmental power, which in turn checks tyranny. ${ }^{11}$ Precisely because there is a value in protecting local decisionmaking power, however, it is important not to overlook the ways in which the absence of visible central intervention may undermine local power.

Admittedly, one must accept that local autonomy is a complex concept before preemptive central lawmaking can be seen as poten-

11. See SHAPIRO, supra note 2, at 58-106 (surveying arguments for decentralization in the federal system); Calabresi, supra note 2, at 774-79 (discussing various arguments in favor of state power, including the possibility of tailored response to local predilections, market competition among regions, experimentation, and improved decisionmaking and administration). For variants of each of these arguments on behalf of decentralization, see generally ALEXIS DeTocqueVILle, Democracy in AMERICA (1840). 
tially productive of local autonomy. We usually think of local autonomy in what might be considered procedural, formal, or ascriptive terms. This way of thinking emphasizes the freedom of local discretion that would exist but for the enactment of a visibly interfering central law. Local autonomy is presented as the natural condition of being free from central interference, and thus central interference is by definition threatening. But that is not the only way-let alone the best way-of understanding local autonomy. We also can understand local autonomy in what might be considered substantive, material, or descriptive terms. This way of thinking emphasizes the freedom of local discretion that would be produced by altering the kinds of limits on local authority that are already, and necessarily, established by less visible provisions of central law. Local autonomy then becomes denaturalized; it is always a function of the way that central law structures the effective decisionmaking capacity of local entities. Preemptive central lawmaking, by this way of thinking, is as likely to be productive of local autonomy as it is to be threatening to it.

Importantly, an acceptance of this way of thinking does not render all exercises of central power the same when viewed from a localist perspective. The fact that central power shapes local autonomy does not mean that all exercises of central power promote local autonomy. Consider, in this connection, two very different ways of justifying central legislation. One way is centralist; it seeks to justify central legislation in the name of vindicating some independent interest of the central government—say, equality or efficiency - that would be frustrated by respecting local autonomy, no matter whether we understand that concept in the usual way or in the more complex way described above. Central laws that have this end do not seek to promote localist values; they seek to trump them. Their purpose is to substitute a central decisionmaker for the more selfish or less competent local decisionmaker that otherwise would have control. The other way of justifying central legislation is localist. It draws on the substantive, material, or descriptive way of understanding local autonomy, and seeks to defend central lawmaking as a useful response to less visible constraints on local decisionmaking capacity that already have been imposed by separate, background provisions of central law. The purpose of these laws is to empower local governments to make policies that the current, centrally established legal regime constrains them from making. Central laws that have this end do not seek to trump localist values; they seek to promote them in a way that the prior legal regime foreclosed. 
To see what underlies the distinction, imagine the following case:

Local governments are free, under state law, to decide whether to provide protection against private discrimination on the basis of sexual orientation. The state legislature is considering legislation to bar such discrimination. ${ }^{12}$

Does this state legislation pose a threat to local autonomy? One might conclude that it does, but nevertheless try to justify it along distinctly centralist lines. One might concede that, in the absence of state legislation, local governments have the autonomy to resolve this issue as they wish. One could conclude that, in the absence of the preemptive state legislation, it is quite likely that each local jurisdiction has the power to decide whether to provide such protection on the basis of its own judgment about the community's need for such measures, the morality of the measures, and the costs they would impose on current residents. On this view, the background legal structure that central law has established does not have a significant influence on the local government's decisions regarding the adoption of such ordinances. ${ }^{13}$

Accepting this account, one still could defend the state legislation. The defense of the state statute would have to proceed, however, along the lines familiarly used to defend centralization against the pathologies of decentralization. One would need to argue that there is a special need to protect minority rights, ${ }^{14}$ a peculiar risk of faction at the local level $;{ }^{15}$ or a transcendent moral imperative that the state as a whole must recognize uniformly. ${ }^{16}$ In other words, the de-

12. The argument works the same way if its analysis starts from the assumption that the state legislature is considering enacting a law that would bar local laws prohibiting such discrimination.

13. For an argument that local governments make judgments on this issue in just this way, see Equality Foundation of Greater Cincinnati, Inc. v. City of Cincinnati, 128 F.3d 289, 291 (6th Cir. 1997) (upholding a local amendment to the city charter precluding the city council from adopting ordinances conferring "special class status ... based upon sexual orientation, conduct or relationships") (citation omitted). Of course, even this way of thinking naturalizes the local governmental boundaries themselves. Were central law to set the local entity's boundaries differently, the "local" decision might change as well. But here, the central government is not choosing to change local boundaries; it is instead choosing to ignore local decisionmaking institutions altogether.

14. See The Federalist No. 10, at 77-84 (James Madison) (Clinton Rossiter ed., 1961) (discussing the role of a large union as a bulwark against factionalism).

15. See id. (noting the advantages of a republic over a democracy and a large over a small republic in containing the influence of factious leaders beyond their particular states).

16. See RonAld DWORKIN, LAW's EMPIRE 178-84 (1986) (discussing concerns with the 
fender of state intervention would justify the infringement on local autonomy in the name of a state policy that would be frustrated by respecting the values associated with local autonomy. The centralist tilt of this defense depends upon the premise that local governments would enjoy autonomy in the absence of the state intervention. Because there is force to the intuition that local autonomy exists in the absence of central lawmaking, the defender of the central intervention must justify its exercise by emphasizing the costs of respecting local autonomy. ${ }^{17}$

Consider, on the other hand, another case concerning state preemption in which the localist argument for central lawmaking is quite easy to articulate.

Local governments are not, in the absence of state intervention, free to determine the amount of resources they allocate to improving air quality. Local decisionmaking is constrained by the approaches to improving air quality that are adopted in neighboring jurisdictions. A neighboring jurisdiction that is lax in policing air quality, or that encourages its industry to locate at the perimeter, may powerfully affect its neighbor's choices about the resources that should be devoted to combating air pollution. The state legislature is considering a law to preempt lax air pollution policies. ${ }^{18}$

legitimacy of "checkerboard laws" on matters of principle); SHAPIRO, supra note 2, at 50-57 (discussing the need for national power to safeguard individual and group concerns).

17. If one doubted whether something meaningfully understood as local autonomy would exist in the absence of state intervention, then one could defend the state intervention along localist lines. For example, the threat to local autonomy would not be so stark if one were convinced that state law rules that promote interjurisdictional competition-rules such as those permitting each locality to retain the taxes that it levies-for employers (or employees) were in fact constraining the choices of many local governments prior to the passage of the preemptive statute. The desire not to be marked as a locality friendly (or unfriendly) to gays and lesbians might constrain local autonomy in a way that it would not be constrained if the local jurisdiction were truly an island or if the state law rules defining local power were different. To be sure, in "freeing" localities from the grip of competition or altering the social meaning of choosing to adopt (or not adopt) a state or local law in this area, the state legislation also would be imposing legal obligations in jurisdictions that had not themselves wished to have its residents subject to such antidiscrimination obligations. But one concerned with protecting local autonomy would want to know the extent to which, in preventing those localities from resolving the matter as they chose, the state legislation also was making it possible for other local governments to adopt gay rights ordinances that would not have been possible under the prior state law regime.

18. Again, for present purposes, the problem is no different if the state law would preempt local discretion in a way that would exacerbate the negative externalities imposed by the neighboring locality. 
Does this state legislation infringe local autonomy? The localist defense of the statute is easily offered. The preemptive statute clearly would limit local autonomy in some respects. It would frustrate the policy choices of those jurisdictions with lax air pollution laws, and it would prohibit all local jurisdictions from enjoying the freedom to adopt the now-barred policy. But it also would enhance the decisionmaking discretion of those local jurisdictions now subjected to extralocal costs by the absence of central preemption of lax air pollution policies. These jurisdictions could allocate more resources to other policies they wished to pursue if they no longer had to respond to the negative externalities imposed upon them by their neighbors-negative externalities that the prior rules of central law required them to accept.

There is, in a case of this type, no clear baseline from which an argument for local autonomy can proceed. ${ }^{19}$ There are localist arguments both for and against the central law at issue. Local autonomy is in one sense limited by the preemptive central command that directly seeks to constrain the exercise of local power. Viewed from a different baseline, however, local autonomy already is limited by background, centrally established, legal rules that define the horizontal relations between localities and permit some localities to avoid costs that others are then required to bear. From this perspective, the absence of a central law that attempts to alter these preexisting, centrally established, horizontal legal relations itself limits local autonomy. Thus, a case of this sort requires the central government to make a policy judgment about the type of local autonomy that it wishes to promote rather than a choice about whether to trump local autonomy in the name of some greater central governmental interest.

The state government's choice to adopt the preemptive law might depend on an independent assessment of the state's interest in combating air pollution-say, a judgment that requiring the costs of pollution to be internalized will promote cleaner air statewide.$^{20}$ But it

19. Cf. Sunstein, supra note 4, at 874-75 (discussing the problem of baselines in connection with individual constitutional rights).

20. For arguments that emphasize the suboptimal national environmental policy that might result from protecting local autonomy from central intervention in the face of negative externalities, see SHAPIRO, supra note 2, at 40-42 (arguing that "when market imperfections call for some regulatory action, social welfare is more likely to be maximized when such action is taken on a national level"); Richard L. Revesz, The Control of Interstate Environmental Externalities in a Federal System, 38 ARIZ. L. REV. 883, 883-85 (1996) (arguing for the "internalization of interstate environmental externalities in a federal system" in the context of the Clean Air Act). 
also might depend upon an assessment of whether state intervention would free more local jurisdictions from extralocal pressures than it would constrain, or upon whether it would relieve local jurisdictions of qualitatively or quantitatively greater constraints on their autonomy than they would confront in the absence of the central law. In making that assessment, one would have to count the likelihood that state air quality would improve as a benefit of the potential state intervention. But one also would have to count as a benefit the likelihood that many local jurisdictions would have more resources to devote to other governmental projects at the local level-resources that otherwise would be devoted to attending to the costs imposed upon them by their neighbors.

In this way, the call for central action rests less on a fear that respecting local power will undermine a more general, statewide interest than on a recognition that the opportunities for the exercise of local power might be enhanced by preemptive action that removes existing constraints on local discretion. A recent cartoon in the New Republic well illustrates the idea. It depicts a factory in one state billowing smoke across the state line. A citizen of each state stands at his respective border. The citizen of the state that is home to the factory says: "The EPA turned pollution regulation over to our state and we're turning it over to yours." ${ }^{21}$ Limiting central power in this context does not promote local autonomy in any obvious way.

The pollution hypothetical highlights a broader point about the autonomy of local jurisdictions in the absence of visible central intervention. A locality's autonomy may in fact be constrained in a number of ways by background rules of central law that too often are taken to be natural. The ways central law requires local jurisdictions to accept the costs of direct negative externalities-like pollutionfurnishes only one example..$^{22}$ Local autonomy also may be constrained, as has already been suggested, by the competitive pressures that central law permits local jurisdictions to impose upon one another. ${ }^{23}$ Local autonomy also may be limited by broader forces

21. Tom Toles, New RePublic, Aug. 6, 2001, at 8 (cartoon).

22. With respect to negative externalities, at the national level, consider the fact that states are limited in their power to adopt protectionist legislation. See, e.g., City of Philadelphia v. New Jersey, 437 U.S. 617, 629 (1978) (invalidating a New Jersey statute prohibiting importation of out-of-state waste).

23. It is arguable that federal intervention to restrain interjurisdictional competition cannot be defended on localist grounds. Since a restraint on competition in one area will just result in the competition moving to another area, ultimately the only way to upend interjurisdictional 
in the private market that no local jurisdiction is equipped to address on its own, given the way central law defines local power. ${ }^{24}$ Finally, a local entity's autonomy may be constrained by still other, less visible provisions of central law that impose burdens that would be left in place even if the supposedly infringing central governmental statute were invalidated or repealed. ${ }^{25}$ The effects of these extralocal constraints may be just as burdensome on local autonomy, as a practical matter, as would the effects of the new, preemptive central law that may be challenged by a particular locality. Each of these constraints would remain in place, however, even if that challenged central intervention were prohibited.

As a result, the effort to protect local autonomy may be incomplete, and perhaps counterproductive, unless one considers how the particular central intervention that is the object of localist ire interacts with these less visible centrally imposed constraints. A failure to do so only encourages a committed localist reflexively to favor the distribution and kind of local autonomy that existed prior to the challenged central intervention and to overlook the possibilities for localism that the challenged central law might bring forth. Attention to the way central lawmaking may relieve extralocal constraints demonstrates, therefore, that more is at issue in many central-local clashes than the relative merits and demerits of permitting the central government's interest to trump the virtues of protecting local autonomy. Also at is-

competition is to nationalize decisionmaking completely. See Richard L. Revesz, The Race to the Bottom and Federal Environmental Regulation: A Response to Critics, 82 MINN. L. REV. 535, 540 (1997) (noting that in the context of environmental regulation, the federalization of all regulatory and fiscal decisions is necessary to prevent suboptimal lax standards); Richard L. Revesz, Rehabilitating Interstate Competition: Rethinking the "Race to the Bottom" Rationale for Federal Environmental Regulation, 67 N.Y.U. L. REV. 1210, 1244-47 (1992) (concluding that the "race-to-the-bottom argument is an argument against federalism"). In addition, one might contend that the very point of protecting local autonomy is to promote interjurisdictional competition. From this perspective, interjurisdictional competition cannot be understood as a threat to local autonomy. It is simply the natural byproduct of protecting local autonomy. Such a contention would, of course, have to be defended against other plausible accounts of what should be understood to be a natural byproduct of respecting local autonomy-such as, for example, cooperation rather than competition. Whatever the merits of these contentions about the relationship between interjurisdictional competition and local autonomy, none of the examples that follows involves federal statutes that are justified as necessary to forestall suboptimal interjurisdictional competition.

24. See, e.g., Fry v. United States, 421 U.S. 542, 548 (1975) (upholding federal legislation to freeze wages paid by state and local governmental employers in the face of severe national inflation).

25. For a similar point, see PAUl E. PETERSON, City Limits 66-92 (1981) (arguing for a new theory of federalism to explain interaction among governmental levels). 
sue are the definition of "local autonomy" and whether it would be well protected in the absence of a particular central law.

To be sure, the contention that preemptive central lawmaking may promote local autonomy relies on arguments for central power that are in some respects familiar. It is hardly novel to contend, for example, that central lawmaking may be needed to respond to interlocal externalities or to effectuate interlocal redistribution. However, these classic arguments for central power often are understood as centralist arguments for the promotion of some value-such as efficiency or equal treatment - that can be realized only by acknowledging and overcoming the pathologies that attend smaller-scale decisionmaking. This way of understanding the function of central power is a partial one that has important and unfortunate consequences. If the successful defense of each central intervention depends upon emphasizing the costs of respecting local decisionmaking authority, then an argument for central power inevitably invites the counterargument that central power threatens the values protected by local autonomy. Once one sees the localist dimension in these classic arguments for central intervention, however, the calculus changes. The conventional rejoinder to such exercises of central power becomes weaker when the central law can be understood to promote the values associated with the preservation of local autonomy. Moreover, the argument for central power no longer points inevitably towards ever-increasing centralization. To be defended credibly on localist grounds, the central law must be shown to promote local discretion even as it also limits it. It is not enough to show that it promotes some value of worth to the central government as a whole.

One final point should be emphasized. The mere fact that a preemptive state law sets forth a state policy that may be preferred by the residents of some localities does not mean that it thereby vindicates localism. A state law that limits pollution is not localist just because residents in a majority of local jurisdictions prefer clean air. For the central intervention to be localist in the way I intend, the state law would have to promote the capacity of the local government to adopt policies that current central law frustrates. Preference matching alone, therefore, does not suffice to promote the values associated with localism. Those values are promoted only when central law changes the background legal rules in a way that expands-even as it also may contract-the opportunities for local governments to achieve preferred policies for themselves. Thus, a state law against 
pollution is localist only because it frees localities from extralocally imposed costs that limit the kinds of policy choices they can make.

With this background in place, it is useful to turn to a consideration of the law of localism. Such an examination reveals that much state lawmaking that appears to threaten local autonomy is defensible on localist grounds. It then will be possible for those attracted to a localist orientation to see some of the problems with the United States Supreme Court's recent federalism decisions.

\section{THE LAW OF LOCALISM}

When we consider the relations between states and their local governments, it immediately becomes clear that significant complications arise for those interested in protecting local autonomy. State law plays a very visible (if often ignored) role in defining what local autonomy means for local governments. As a result, a state law that appears to limit local autonomy when viewed from one baseline, actually may promote it when viewed from another.

\section{A. The Breadth of Formal State Power}

The way that central law operates to protect local power is complicated. As a formal legal matter, the federal Constitution does not treat local governments as anything approximating coequal sovereigns. ${ }^{26}$ States have the power to approve and establish local governments. That is true as a matter of state constitutional law as well. State legislatures have broad powers to structure the internal governance structure of local governments and, in certain circumstances, to, in effect, place them in receivership. ${ }^{27}$

In addition, state legislatures possess the formal legal power to delegate large swaths of authority to their local governments or to

26. See, e.g., Hunter v. City of Pittsburgh, 207 U.S. 161, 178 (1907):

Municipal corporations are political subdivisions of the State, created as convenient agencies for exercising such of the governmental powers of the State as may be entrusted to them. For the purpose of executing these powers properly and efficiently they usually are given the power to acquire, hold, and manage personal and real property. The number, nature and duration of the powers conferred upon these corporations and the territory over which they shall be exercised rests in the absolute discretion of the State.

27. See, e.g., Powers v. Sec'y of Admin., 587 N.E.2d 744, 751 (Mass. 1992) (upholding a state-imposed receiver against a state constitutional home rule challenge). But cf. City of La Grande v. Pub. Employe[e]s Ret. Bd., 576 P.2d 1204, 1208 (Or. 1978) (suggesting that state constitutional home rule provisions might limit the state's powers to regulate the form of local governmental organization). 
withhold such powers from them as the legislatures choose. ${ }^{28}$ They possess as well the authority to commandeer local governments to perform certain tasks, and, in many circumstances, to impose unfunded mandates upon them. ${ }^{29}$ State governments also possess the power to set limits upon the authority of local governments to raise revenue for themselves and the power to redistribute that revenue among localities. ${ }^{30}$ In short, state constitutional law overwhelmingly favors expansive state supremacy over local governments.

Indeed, some of the more significant state constitutional limitations on the state's power to define its relationship to its local governments expressly point in the direction of ensuring state supremacy. For example, some state constitutions expressly limit the state legislature's authority to augment the power of local governments to borrow money. ${ }^{31}$

There is a countervailing tradition in state constitutional law. There have been contentions that inherent in the state constitutional system is a traditional right to local self-government that is intended to protect the local sphere from central intrusion. Thomas Cooley, Amos Eaton, and other now-forgotten figures from the latter part of the nineteenth and early part of the twentieth century, made an effort to put forth such a claim. Their claims by and large failed, however. ${ }^{32}$

More importantly, there has been a longstanding tradition of home rule that began in 1875 and that has persisted over time. ${ }^{33}$ The

28. See Frank I. Michelman \& TERRAnce SANDAlow, Materials on Government IN URBAN AREAS: CASES-COMMENTS-QUESTIONS 234-51 (1970) (discussing the issue of delegation of power to local governments).

29. U.S. ADVISORY COMM'N ON INTERGOVERNMENTAL RELATIONS, MANDATES: CASES IN STATE-LOCAL RELATIONS 4-6 (1990). There are, however, state constitutional provisions that require such mandates to be funded. See, e.g., ME. CONST. art. IX.

30. See, e.g., Gerald Frug, Richard T. Ford \& David J. Barron, Local GOVERNMENT LAW 655-57 (3d ed. 2001) (noting the limitations that states often impose on the ability of cities and municipalities to generate revenue); OSBORNE M. REYNOLDS, JR., LOCAL GOVERNMENT LAW 110-12 (2d ed. 2001) (discussing conflicts between state and local governments over financial matters).

31. See, e.g., Mun. Bldg. Auth. v. Lowder, 711 P.2d 273, 277 (Utah 1985) (discussing the importance of such limitations under the Utah Constitution); REYNOLDS, supra note 30, at 30918 (discussing state constitutional debt limits generally).

32. See David J. Barron, The Promise of Cooley's City: Traces of Local Constitutionalism, 147 U. PA. L. REV. 487, 487-546 (1999) (discussing Cooley's conception of a right to local selfgovernment); Gerald E. Frug, The City as a Legal Concept, 93 HARV. L. REV. 1059, 1113-17 (1980) (discussing Cooley and Eaton and the failure of their approach to win adherents).

33. See generally Dale Krane et Al., Home Rule in America: A FifTy-State HANDBOOK 1-21 (2001) (discussing the history, policy, political philosophy, and social importance of home rule among the nation's fifty states). 
majority of states now confer some constitutionally recognized measure of home rule power upon local governments. Home rule provisions typically confer upon municipalities power over local or municipal affairs. These provisions are themselves reflective of the expansive nature of formal state power over local matters.

Home rule provisions perform two quite distinct functions. On the one hand, they are mini-Tenth Amendments designed to cordon off local matters from state intervention. They provide a constitutional defense against state assertions of preemptive power. Very few state cases, however, have construed these home rule provisions in this fashion. It is the relatively rare state court case that holds the state legislature unable to intervene on a matter over which a local government wishes to exercise control. The other function is a powergranting function. Local governments do not possess reserved powers in the way that states do. They are creatures of their states and possess only those powers that the states specifically have chosen to vest in them. No powers arise simply from the fact that they are "governments." Traditionally, particularized state grants of power have been construed narrowly to ensure that the delegate relationship is preserved. Home rule provisions serve the important function, then, of enabling local governments to operate and exercise authority in the absence of a particularized grant of state power. They are a kind of mini-Article I for local governments, in the sense that they enumerate their authority over local or municipal affairs. ${ }^{34}$ But in doing so, they grant power to local governments to act; they do not immunize local actions from state preemption.

It is fair to say that hardly any impediments to the exercise of state power vis-à-vis local governments exist in state constitutional law, and certainly none exist that would be comparable to the kind of impediments now being adopted in the United States Supreme Court's recent federalism cases. There are few, if any, matters of concern to state residents that, as a formal legal matter, the state legislature would be barred from addressing because of the need to respect the rights to self-government of local communities. ${ }^{35}$

34. See Terrance Sandalow, The Limits of Municipal Power Under Home Rule: A Role for the Courts, 48 MinN. L. REv. 643, 648-52 (1964) (discussing grants of authority to municipal governments and limitations placed on state legislatures' authority to legislate concerning municipal issues as separate aspects of home rule).

35. It would be too much to say that there are no such limits. For example, some courts have invalidated state legislation mandating revenue-sharing as violating state constitutional protections for what it deems to be local autonomy. See, e.g., Buse v. Smith, 247 N.W.2d 141, 
In this respect, local governments might seem to stand in a very different relation to their states than states do to the national government. Whatever the scope of federal constitutional limits on state power should be, it is clear that states never have been understood to be mere creatures of the national government in the way that local governments have been understood to be mere creatures of their states. Nevertheless, as the next section shows, state law has proved far more receptive to the ascriptive, formal or procedural idea of local autonomy, and thus to the notion that local freedom depends upon the absence of visible state intervention, than this formal description of state power would lead one to suspect.

\section{B. The Reality of Local Power}

The formal regime of supreme state legislative authority notwithstanding, it is widely perceived that, under state law, local governments enjoy a great degree of what is termed local autonomy under state law. The force of local autonomy as a constraint on state power is the conventional premise from which many contemporary assessments of the state-local relationship proceed. ${ }^{36}$ This premise makes clear that there is no logical connection between a regime of constitutional law that assumes central supremacy and does little to protect local power through judicially enforceable norms and a political environment that favors central over local power. Local autonomy-or, at least, something widely perceived to be local autonomy-is alive and well under state law despite an overwhelming state constitutional premise that localism is to be the exception rather than rule. ${ }^{37}$

To say that state law protects local control is not to explain, however, what is meant by that statement. What is it about state law, as currently constituted, that makes it sensible to conclude that it protects local control? Three features of state law commonly are identified as evidencing its localist character. Each appears to be funda-

143 (Wis. 1976) (striking down state-mandated, interlocal revenue sharing for public education). There also are state constitutional prohibitions against special legislation that may limit a state's capacity to regulate a particular city, but these often are honored in the breach.

36. See, e.g., Richard Briffault, Our Localism: Part I-The Structure of Local Government Law, 90 CoLUM. L. REV. 1, 1-115 (1990) [hereinafter Briffault, Our Localism: Part I] (discussing the influence of localism on American local government law); Richard Briffault, Our Localism: Part II-Localism and Legal Theory, 90 COLUM. L. REV. 346, 346-454 (1990) [hereinafter Briffault, Our Localism: Part II] (discussing the theoretical defenses of localism).

37. See Richard Briffault, The Role of Local Control in School Finance Reform, 24 CONN. L. REV. 773, 776-85 (1990) (explaining the relationship between formal state supremacy and local control in the area of public education). 
mental to local control; by and large, state law seems to regard each feature as a key power of local communities that states are loathe to upset.

The first feature is the way that state law structures the funding of local governments. States might choose to fund local governments in a variety of ways. Revenues could be raised exclusively by statewide income taxes that then would be redistributed locally according to some state-sanctioned formula. England does something like this right now: it collects and redistributes not only income taxes but also commercial and industrial property taxes. ${ }^{38}$ Or revenues could be raised locally through taxes, as they are now, but then shared between communities through a state-administered fund. The Twin Cities in Minnesota have pioneered this approach at the regional level. ${ }^{39}$

In the main, however, all fifty states have opted to authorize local governments both to impose taxes locally-whether they be sales taxes or property taxes-and to keep the revenues for the exclusive benefit of local residents. This approach encourages each municipality to conceive of the property-industrial, commercial, and residential-within its jurisdiction as its own tax base, rather than as property open to be taxed for the benefit of the statewide public as a whole. The locally taxable revenue generated by that property does not have to be shared with the state as a whole, or even with neighboring jurisdictions. So workers from the central city who travel to a suburb to work during the day may spend money in suburban stores. The resulting locally set sales taxes are for the suburb to keep. Similarly, the property taxes levied against a downtown office complex are for the central city to keep—no matter how many of the people who work in that building reside in neighboring communities. ${ }^{40}$ Many consider this right to treat property within local boundaries as property available for local benefit alone to be critical to what is understood as local autonomy. ${ }^{41}$

38. See DAVID WiLSON \& CHRIS GAME, LOCAL GOVERNMENT IN THE UNITED KINGDOM 151-94 (2d ed. 1998) (discussing the financing of local governments in the United Kingdom).

39. See Myron Orfield, Metropolitics: A Regional Agenda for Community AND STABILITY 142-49, 152 (1997) (discussing the tax sharing plan in the Twin Cities).

40. See FRUG, supra note 9, at 104-05 ("By defining the tax base in terms of the property found within a jurisdiction and by defining the beneficiaries of the tax base in terms of residency, local government law creates and intensifies inequality within the metropolitan area.").

41. See, e.g., Briffault, Our Localism: Part II, supra note 36, at 349 ("The logic of local legal autonomy assumes local solutions to local problems, with local programs funded by taxes on local property."). 
Certain exceptions are made to this general system when some fundamental right is at issue. Many states have recognized this point in the context of school funding. These states generally have justified a departure from the typical rules regarding which locality "owns" local tax revenue by pointing to the special role that education plays in the state or the unique right to a public education granted by the state constitution. Education, then, is thought to be a sufficiently important statewide matter to justify an exception to the normal rules of play, rules that are taken for granted as the essence of our system of local self-government. ${ }^{42}$

The second feature of state law evidencing its localist character is the way that state law structures the exercise of certain local police powers, such as the regulation of land use, within local boundary lines. Again, land-use decisions could be handled within a state in a variety of ways. Generally speaking, however, most states-and until relatively recently nearly all states-have settled on a single course: largely unconstrained local land-use authority. ${ }^{43}$ As a result, state law generally authorizes local governments to determine how much, if any, commercial property will be permitted within certain areas of the municipality. It authorizes them to determine as well what kinds of housing will be permitted within municipal limits. Will the land within the municipality be zoned only for single-family housing or will multifamily housing be permitted as well? Will manufactured housing be excluded or permitted? Will apartment dwellers be welcomed or shunned? Will lot sizes be large or small? Will garages be required or forbidden? Most states have long since determined that the answer to each of these questions is appropriately the province of local decisionmaking. And land use is not the only policy area in which such discretion is conferred. ${ }^{44}$

The final localist aspect of state law concerns the very definition of what constitutes a local government. State law leaves local government formation largely to the discretion of the persons within a particular territorial space. Persons within an area are permitted to form a local government through incorporation, often with little or no

42. For a comprehensive listing of the relevant cases, see Kelly Cochran, Comment, Beyond School Financing: Defining the Constitutional Right to an Adequate Education, 78 N.C. L. REV. 399, 402 n.22 (2000).

43. See Briffault, Our Localism: Part I, supra note 36, at 19, 39-48 (1990) (describing state law as generally allowing for "unfettered local control over land use").

44. See Briffault, supra note 37, at 785-99 (discussing local control over educational policy). 
meaningful state-level review. ${ }^{45}$ And, in addition, annexation is made quite difficult under state law so that local governmental integrity is preserved once established. ${ }^{46}$ Local governmental power to avoid consolidation is preserved further by generous state law rules that permit local governments to preserve their integrity and to contract for services to avoid having to expand their boundaries to encompass residents of less affluent districts. ${ }^{47}$ As with the previous two examples, alternative approaches are possible. For example, states rigorously could police the formation of new local governments, treating each new entity as a kind of administrative agency that could be formed only in the event that the state legislature thought it beneficial to do so. ${ }^{48}$

These three features make state law appear solicitous of local power. First, the revenues for each local government are generated to an important degree internally, such that the wealth within a jurisdiction is understood to be the taxable prey of that jurisdiction alone. Second, broad delegations of land use and other police powers make each of these seemingly pre-political, and inviolable, republics free to exercise power within its domain of authority. Finally, the generous rules concerning local government formation make each local government appear to be the consequence of pre-political action rather than state law construction. ${ }^{49}$ The preservation of the territorial integrity of local governments once formed, moreover, affords them a degree of indestructibility that mimics that enjoyed by the states themselves.

These three aspects of state law combine to ensure that states leave many of the critical issues that confront the residents of every state-housing, education, crime, explosive growth and related prob-

45. See Briffault, Our Localism: Part I, supra note 36, at 73-77 (discussing the relative freedom and autonomy of local municipalities in the context of incorporation).

46. See Kenneth Jackson, Crabgrass Frontier: The Suburbanization of the UNITED STATES 138-56 (1985) (describing the increased powers of localities to resist annexations); Briffault, Our Localism: Part I, supra note 36, at 77-81 (arguing that many state laws concerning annexation are inherently localist).

47. See Gary Miller, Cities by CONTRACt 17, 20-22, 34-37, 81-85 (1981) (discussing what is known as the Lakewood Plan, which permitted interlocal contracts that empowered some communities to incorporate and resist annexation).

48. Id. at 100-03,107-10.

49. See Richard Ford, Geography and Sovereignty: Jurisdictional Formation and Racial Segregation, 49 STAN. L. REV. 1365, 1365 (1997) (describing how state and federal law treats the formation of local governments as an act of passive recognition of an already extant community rather than affirmative state action to create such a community). 
lems of sprawl-to local governments in important respects. In other words, insofar as the state has intervened-and, of course, states have had no choice but to intervene, given that local governments are creatures of state law-they often have intervened in a manner that produces what is known as "local control."

To the extent that local governments understand the powers they exercise as their powers, committed to them as a matter of a seemingly pre-political right to self-determination, any effort by the state to limit them is understood as a direct threat to local autonomy. The experience of state-local relations suggests that once this way of thinking about local control takes hold, it is difficult to overcome. State law in this way creates local autonomy of a certain kind: one that depends on the freedom of local governments to keep the taxable property in their jurisdiction from being available to benefit their neighbors; the power of local governments to decide land use and other regulatory matters on their own, without regard to the interests of neighbors; and the ability of persons in a limited geographical area to establish themselves as a distinct government entity, blessed with the two "rights" mentioned above, and relatively immune from being "forced" to join a neighboring jurisdiction.

\section{Reconsidering the Law of Localism}

Given the localist character of important features of the state law governing state-local relations, how are we to think about state attempts to change those features? One way would be to treat such attempted changes as clear, central government threats to local autonomy that may be justified, if at all, only by appeals to the arguments commonly offered in favor of central authority. One would note the broader constituency of the state government and its greater size, making exit from its jurisdiction more difficult. As an extended sphere, the state might overcome the baleful consequences of respecting local autonomy. ${ }^{50}$ So with respect to the three localist features of state law described above, one could argue that fiscal policy should be a state rather than a local matter to promote uniform norms of equity; ${ }^{51}$ that land-use policy should be handled centrally

50. See Briffault, Our Localism: Part II, supra note 36, at 447-54 (arguing that "states' greater geographic scope, superior fiscal resources and social and economic heterogeneity give them a greater capacity to control local externalities and address interlocal and interpersonal wealth differences").

51. Cf. PETERSON, supra note 25, at 82 (suggesting that the national government is best 
rather than locally to counteract the parochial instincts of local folk; and that state interests in ensuring orderly metropolitan development necessitate state control over questions of local governmental formation and annexation that selfish local actors would undermine if left to their own devices.

Arguments like these assume that central intervention poses a threat to local autonomy that may be justified by an appeal to some overriding statewide concern-a concern often rooted in a distrust of local governmental actors. Such arguments frame disputes over retention of these localist aspects of state laws as disputes between the virtues of centralization and the virtues of decentralization. Participation and free choice are promoted by respecting local autonomy; the virtues of uniformity and less selfish decisionmaking are promoted by extending the sphere.

This framing of the dispute is problematic. Once it is acknowledged that localities exist within a broader state law legal structure, the claim that there is an autonomous or reserved local sphere that must be protected from the state becomes suspect. Central law defines the possible powers of that local sphere, and central law, by definition, must impose limits upon the possible scope of local power-even when it appears, on its face, to do nothing more than promote local autonomy. The invocation of the primacy of local authority-understood as the inviolability of the particular powers that states have given localities at the present time-obscures this feature of local control within states. It fosters the illusion that there is some Eden-like state in which local communities exist free of any central limitations on their powers. And in doing so, such an invocation of local primacy implicitly naturalizes the particular powers that now seem to constitute local autonomy, as if local autonomy as such could not exist unless those specific powers were protected from state attempts to alter them. As a consequence, this way of framing the dispute forecloses other understandings of what local autonomy could mean.

Consider in this regard the recent state supreme court decisions invalidating state systems for funding public education through local property taxes. ${ }^{52}$ One might conclude that questions of school financing sharply pit arguments for centralization against arguments for de-

suited to making redistributional decisions because of the structural differences between it and lower levels of government).

52. See Cochran, supra note 42, at 402-04 n.22 (2000) (listing these decisions). 
centralization. There is a certain intuitive force to framing the issue in this way. After all, the school financing decisions seem to limit local autonomy in an area in which there is fairly broad agreement that it is important to respect it. The decisions certainly have the consequence of requiring wealthy communities to share some of their taxable property base with neighboring jurisdictions. The decisions therefore make the funding of local public schools dependent upon external funding sources and deprive local communities of the autonomy that accompanies budgetary control. They seem to require unprecedented assertions of central authority that would upset longstanding traditions of local educational control. Indeed, in this sense, the decisions appear to conscript local governments through central commands to administer a state system of public education. Local governments that want to spend their tax dollars only on their own schools are required to share revenues with other districts. ${ }^{53}$

But framing the issue this way ignores the impact of the state law rules that were in place prior to the restructuring of school financing systems. As many state courts, ${ }^{54}$ and even some dissenting federal judges, have recognized, ${ }^{55}$ the state-conferred entitlement to retain locally raised taxes, and the state-imposed limitation on revenue sources, empower wealthy communities and disempower poorer ones. A change in these background state law rules, therefore, frees poorer localities from the limitations on budgetary choices that they face as a consequence of a state law regime that ties local educational policy to local taxable wealth. ${ }^{56}$ State-imposed mandates to share revenue in this way enhance the local decisionmaking discretion of relatively poor communities that at present must set educational policy within a state law system that restricts their available funding sources to local

53. See Buse v. Smith, 247 N.W.2d 141, 143 (Wis. 1976) (applying similar logic to invalidate, under the Wisconsin Constitution, a state law requiring compulsory sharing of local property taxes for education).

54. See Cochran, supra note 42 , at 402-11 (discussing the early positions taken by several state courts that reliance on local property taxes for public school funding violated students' equal protection rights).

55. See San Antonio Indep. Sch. Dist. v. Rodriguez, 411 U.S. 1, 68 (1973) (White, J., dissenting) (arguing that the use of property taxes to fund public education is violative of the Equal Protection Clause).

56. See generally John E. CoOns et al., Private Wealth and Public Education (1970) (proposing, inter alia, that legal challenges be brought against such systems of funding due to their impact on poorer communities); Frank Michelman, Foreword: On Protecting the Poor Through the Fourteenth Amendment, 83 HARV. L. REV. 7 (1968) (addressing the constitutionality of inequities in school financing systems). 
property taxes. For these communities, local discretion with respect to matters of educational policy likely will be enhanced by requiring all localities to share some of their taxable wealth.

Even if we agree that it is important to protect local control over education, in other words, we still would be left with the problem that such agreement does not yield an answer to how these state constitutional challenges to inequitable school funding should be resolved. Appeals to local control simply restate the dilemma. They do not help to resolve it. In fact, they help to obscure it. They make the choice a categorical one-education is either a matter for local control or it is not. And they help to entrench current understandings of what constitutes local control at the expense of future ones by subjecting any change in the centrally established legal framework within which local governments operate to the criticism that it has infringed on the imperative of protecting local control. Pointing out that appeals to localism are indeterminate undermines the view that central intervention is antithetical to localism, whenever central law appears to limit the existing quantum of discretion that localities exercise. If one believes wealthy districts are entitled to hold on to their current property taxes, then one must argue for that particular vision of local autonomy and not simply for the more neutral-sounding concept of localism writ large.

To see another way in which a seemingly anti-local state law intervention actually can enhance local control, consider an important set of state law cases from New Jersey. In 1975, the New Jersey Supreme Court in Southern Burlington County NAACP v. Township of Mount Laurel (Mount Laurel I) ${ }^{57}$ invalidated a state statutory system of local zoning that permitted each town to zone out all multifamily or low-cost housing opportunities. ${ }^{58}$ Here was an area of public policy-local land use - that had long been left to local decisionmaking. Here was the state-through its courts no less-intervening to diminish the authority of each local government to zone as it wished.

The court held that the zoning power must be exercised for the general welfare of the state, ${ }^{59}$ and thus its decision could be read to suggest that it was treating the case as one about protecting statewide welfare from the consequences of respecting local autonomy. But the decision suggests a different reading as well, a reading in which

57. 336 A.2d 713 (N.J. 1975).

58. Id. at 734 .

59. Id. at 725 . 
Mount Laurel I is not a case about the advantages of centralization trumping the advantages of decentralization. The court made clear that local power already was constrained prior to its decision. Prior to Mount Laurel I, a state system of property taxation that encouraged zoning to take a certain exclusionary cast powerfully induced towns to zone in certain ways. ${ }^{60}$ To keep taxes low, the towns had incentives to zone out persons-children and the poor-who would require substantial services. Indeed, the towns were frank in making this argument as a defense to the suit in Mount Laurel I. The towns portrayed themselves before the court not only as defenders of a right to local self-determination but also as the hapless subjects to a state law property tax regime that gave them few real options other than "fiscal zoning." ${ }^{61}$ And the towns shunned by wealthier people suffered the externalities imposed upon them by the exclusionary zoning of wealthier jurisdictions. They became the places of "choice" for lowincome people because the poor had no way of relocating to surrounding suburbs due to the zoning restrictions adopted in those places. Their power over their resources, in this sense, was powerfully constrained by the power exercised by their neighbors. ${ }^{62}$

Moreover, Mount Laurel I did more than simply substitute new constraints on local zoning practices for old ones. The decision also arguably enhanced the power of local governments to exercise their zoning powers in ways that would have been legally suspect prior to the decision. The Mount Laurel I decision held that, under the state constitution's general welfare clause, developing municipalities were obliged to zone in a manner that made available a reasonable opportunity for low-income housing developers. ${ }^{63}$ The court did not at that time prescribe a method by which such opportunities should be made available, and local governments largely resisted the force of the order. ${ }^{64}$ In response, the court in Southern Burlington County NAACP v. Township of Mount Laurel (Mount Laurel II) ${ }^{65}$ ordered localities to take affirmative measures to make low-income housing opportunities available. ${ }^{66}$

\footnotetext{
60. Id. at 723 .

61. Id. at 731-32.

62. Id. at 733-34.

63. Id. at 728 .

64. See Briffault, Our Localism: Part I, supra note 36, at 52 (noting that local governments

"dug in their heels" and "remained inactive" following the Mt. Laurel I decision).

65. 456 A.2d 390 (N.J. 1983).

66. Id. at $443-48$.
} 
Interestingly, as municipalities began to exercise their zoning powers to respond to this second decision, they came under attack from developers newly subject to locally adopted inclusionary zoning measures-provisions that required developers to pay into an affordable housing fund in order to build, to set aside a certain number of low-income units in new housing developments, or permitted them to build more dense housing developments only if they agreed to such set-asides. In bringing these challenges, the developers contested the authority of local governments to exercise their zoning discretion in this inclusionary manner. They argued that the state zoning enabling act did not authorize such zoning and that state constitutional limitations on the power of localities to impose taxes expressly forbade it. ${ }^{67}$ They had on their side some precedent from another state that called into doubt the authority of local governments to engage in what had been called "socio-economic zoning," largely agreed. ${ }^{69}$ The New Jersey Supreme Court reversed in significant part $^{70}$ and, in doing so, pointed to its prior interpretation of the state constitution's general welfare clause as support. ${ }^{71}$ In this respect, the Mount Laurel I decision can be understood as altering the state law structure within which local governments necessarily operated by increasing local power, rather than infringing local autonomy to obtain the benefits of centralization. Local governments possessed independent powers to zone after Mount Laurel I that they arguably lacked before it.

Finally, consider a case concerning the last of the three features of state law that gives it a localist cast: the state law rules that promote local territorial integrity. Board of Supervisors of Sacramento County v. Local Agency Formation Commission ${ }^{72}$ concerned a challenge to a state law that permitted residents within a spatially defined territory to petition to form a new municipality. ${ }^{73}$ The law seemed to

67. Holmdel Builders Ass'n v. Township of Holmdel, 556 A.2d 1236, 1240-44 (N.J. Super. Ct. App. Div. 1989). 1973).

68. Bd. of Supervisors of Fairfax County v. DeGroff Enters., Inc., 198 S.E.2d 600, 602 (Va.

69. See Holmdel Builders, 556 A.2d at 1243-44 (requiring that mandatory development fee and set-aside ordinances must provide some compensating benefit to a new developer in order to be sustainable).

70. Holmdel Builders Ass'n v. Township of Holmdel, 583 A.2d 277, 295 (N.J. 1990).

71. Id. at 286 .

72. 838 P.2d 1198 (1992).

73. Id. at 1200 . 
protect local autonomy by permitting persons living within a territorially defined area to determine whether to govern themselves. But in privileging the autonomy of this group of persons, the law potentially infringed the autonomy of neighboring localities that would be adversely affected by the new incorporation. The people of the unincorporated community were, prior to incorporation, residents of the County of Sacramento. ${ }^{74}$ State law rules that made it easy for them to incorporate promoted their interests in autonomy, but only at the expense of the autonomy of the county. Indeed, so strong was the competing claim for local autonomy that neighboring jurisdictions contended that the state incorporation law violated the Equal Protection Clause of the federal Constitution by permitting only the residents of the territory seeking to incorporate to vote on the incorporation decision. ${ }^{75}$

In rejecting this competing claim, the California Supreme Court recognized its force. It upheld the state incorporation law in significant part because the state had attempted to balance the competing claims to local autonomy. ${ }^{76}$ The state had provided an institutional mechanism-a Local Agency Formation Commission comprised of representatives chosen by affected neighboring communities-to ensure that the interests of other localities were taken into account. ${ }^{77}$ In this respect, Sacramento County might be read to suggest that truly liberal municipal incorporation rules, which seem protective of local autonomy, are unconstitutional because they infringe the very real interests of neighboring communities whose interests otherwise would not be taken into account. Indeed, as the California Supreme Court noted, the commission was properly sensitive to the complexity of claims for local autonomy; it approved the incorporation only if two shopping centers were moved outside the borders of the newly incorporated town. ${ }^{78}$ Such a contingent approval was intended to ensure that the county would not be deprived of the sales tax revenue from the shopping centers as a consequence of the commission's recognition of the autonomy interests of the residents seeking to incorporate. Yet one detects even in this approach a particular idea of local autonomy. Not contemplated was a still different conception of local

\footnotetext{
74. $I d$.

75. Id. at 1201 .

76. Id. at 1211

77. Id. at 1200 .

78. Id.
} 
autonomy in which the physical location of the shopping centers would be legally irrelevant because the sales-tax revenues generated by them would be pooled between the county and the new municipality.

Once the complexity of local autonomy is recognized and proponents of localism move away from a blind commitment to preventing new state intervention in areas traditionally left to local discretion, an analysis of the actual impacts of state intervention on local discretion becomes necessary. One must identify those effects of central intervention that are thought to be problematic from a localist perspective, and thus expose them to critical evaluation. Are the negative effects on what is now understood as local autonomy outweighed by competing benefits in the form of enhanced local decisionmaking that would result from the exercise of central power? This question should be relevant to those interested in protecting local autonomy.

Such a localist vision would not be so malleable as to sanction all exercises of central power. The localist argument for central lawmaking takes the justification for the central law to depend in critical respects on its capacity to promote the values that are associated with respecting local autonomy. A localist argument for central power would not sanction, therefore, a central law that would effect wholesale removal of the educational system or the zoning power from the local level to the state-such a shift in law would not promote the effective delivery of such services by localities even though it might promote the general welfare. This vision of localism would be open, however, to shifts in state law that limited local discretion in some respects but enhanced it in others. While effective local service delivery would continue to be an end worth pursuing, proponents of this vision would not be committed to preserving the current institutional arrangements for such delivery that state law has selected. As a result, they would be open to shifts in the centrally established frameworks within which local discretion inevitably is exercised. That openness makes such a vision more amenable to legal changes that might promote more creative exercises of local power than the system currently in place allows. ${ }^{79}$

79. There is a related and difficult question as to the role that local governments should be permitted to play in identifying and approving of the need for such shifts in central frameworks. For some thoughts on how this question might be addressed, see Dorf \& Sabel, supra note 9, at 316-23 (emphasizing the important role that transparent local decisionmaking may play in bringing about shifts in central frameworks). 


\section{THE LAW OF FEDERALISM}

We have seen how state law shapes, rather than limits, local autonomy. When we turn from a consideration of how states protect their local governments to a consideration of how states and local governments are protected from the federal government, a surprisingly similar set of complications arise. Just as the absence of visible state intervention may be understood to infringe local autonomy in the state-local context, so, too, the absence of visible federal intervention can be understood to threaten state and local autonomy. This argument does not depend on establishing a formal equivalence between the state-local and the federal-state relationships. One need not conclude that states, like local governments, are mere creatures of some higher level of government that retains supreme power to determine the autonomy of its subordinates at any moment. One need only recognize that states, like local governments, operate within a broader system that imposes limits on the scope of their powers. As a result, even a very robust law of federalism can be attentive to the ways in which the absence of visible central power may leave state and local governments with less autonomy than they might have if the federal government were permitted to intervene. To see how, it is helpful to compare some important divergences between the federalism revival of the 1970s, as reflected in the United States Supreme Court's important decision in National League of Cities v. Usery, ${ }^{80}$ with the recent federalism revival, as reflected in decisions such as New York v. United States, ${ }^{81}$ Printz v. United States, ${ }^{82}$ United States v. Lopez, ${ }^{83}$ and United States v. Morrison. ${ }^{84}$

\section{A. The Old Federalism Revival}

The key case in the United States Supreme Court's previous attempt to revive federalism is National League of Cities v. Usery. ${ }^{85}$ There, the Court invalidated the application of the Fair Labor Standards Act's minimum wage and maximum hour provisions to certain state and local government employees. ${ }^{86}$ The Court held that constitu-

\footnotetext{
80. 426 U.S. 833 (1976)

81. 505 U.S. 144 (1992).

82. 521 U.S. 898 (1997).

83. 514 U.S. 549 (1995).

84. 529 U.S. 598 (2000).

85. 426 U.S. 833 (1976).

86. Id. at 852 .
} 
tional protections for state governmental sovereignty limited the permissible reach of otherwise valid federal commercial regulation. ${ }^{87}$ The external limitation that the Court imposed on Congress's power was thought necessary to protect against "the utter destruction of the State as a sovereign political entity."'

Much of the opinion's analysis of central-local relations proceeded along conventional lines. The Court sought to identify a sphere of local autonomy that the national government had infringed. The Court explained that application of the Act to state and local governmental employees involved in the provision of "traditional governmental functions" exceeded the bounds of congressional authority. ${ }^{89}$ The majority pointed to the Act's application to employees involved in "fire prevention, police protection, sanitation, public health, and parks and recreation" activities that it described as "typical of those performed by state and local governments in discharging their dual functions of administering the public law and furnishing public services." ${ }^{, 90}$ Such functions, the Court continued, are those that these "governments are created to provide" and that "States have traditionally afforded their citizens."

Under this conventional framework, if a federal statute intruded on the local sphere, the only remaining question was whether an overriding national interest justified such an intrusion. The Court appeared to suggest that a balancing test would be applied to resolve the dilemma. ${ }^{92}$ The interference with local autonomy apparently would be weighed against the national interest in uniformity or protecting the rights of workers or some similarly nationalist interest. The virtues of respecting local autonomy would be pitted against the virtues of centralization.

\footnotetext{
87. $I d$.

88. Id. at 842 (quoting Maryland v. Wirtz, 392 U.S. 183, 196 (1968)).

89. Id. at 852 .

90. Id. at 851.

91. Id. Elsewhere in the opinion, the Court appeared to add to the list "schools and hospitals." Id. at 855 . By contrast, other functions that state and local governments perform were not of a similar constitutional stature. For example, the state or local governmental "operation of a railroad engaged in "common carriage by rail in interstate commerce," $i d$. at 854 n.18 (quoting United States v. California, 297 U.S. 175, 182 (1936)), was not a function that "States have regarded as [an] integral part[] of their governmental activities," $i d$.

92. Id. at 856 (Blackmun, J., concurring) (observing that the Court's holding does not outlaw federal power in areas where federal interests prevail and where state compliance with imposed federal standards would be essential).
} 
Portions of the opinion, however, gesture toward a more complicated understanding of what it means to protect local autonomy. Here, the Court spent considerable time detailing the various ways the federal legislation, by requiring the payment of higher wages, would directly and appreciably disrupt the ability of local governments to provide such vital services. ${ }^{93}$ The involvement of the federal government in a sphere of traditional state and local authority would not suffice to constitute an impermissible infringement of state and local authority. A determination that the legal line had been crossed would depend on a determination that the federal intervention actually impaired the capacity of state and local institutions to deliver those services.

The Court in this way provided room for an acknowledgmentwhether it intended to do so or not-that central constraints on local capacity would remain even in the absence of a directly preemptive central law. Consider in this regard the National League of Cities Court's distinction between the Fair Labor Standards Act that it invalidated and the Economic Stabilization Act, designed to combat national inflation, upheld some years earlier in Fry v. United States. ${ }^{94}$ The National League of Cities Court reaffirmed Fry even though that decision had required states and localities to comply with a federal statutory mandate-the Economic Stabilization Act-to freeze the wages of their employees. ${ }^{95}$ Such federal legislation clearly involved matters traditionally handled at the state and local level, and it clearly interfered with the state and local exercise of policymaking discretion in some respects. Nevertheless, the National League of Cities Court explained that the legislation upheld in Fry potentially assisted in carrying out state and local government functions. ${ }^{96}$

The federal wage and hour legislation invalidated in National League of Cities crossed the line because it called into question the capacity of local governments to continue to employ volunteer firefighters and even to attempt to racially integrate their police forces because of the added expenses it would require them to incur. By contrast, the Economic Stabilization Act, by freezing wages for public (as well as private) employers, "operated to reduce the pressures

\footnotetext{
93. Id. at $846-48$.

94. 421 U.S. 542 (1970).

95. Nat'l League of Cities, 426 U.S. at 852-54.

96. Id. at 853 .
} 
upon state budgets rather than increase them." ${ }^{97}$ In the absence of central intervention to freeze wages, inflation may powerfully constrain a local government's autonomy to set the wages of its employees (and thus to determine what kinds of services may be provided to residents). That is because a local jurisdiction has little power to stem inflation caused by broader national market forces; the national government alone has the power to set national monetary policy and to define what currency may be used. ${ }^{98}$ By contrast, in the absence of central intervention to compel the payment of higher wages, local governments are generally free to make their own judgments, unconstrained by extralocal pressures, as to whether to set wages for their employees above inflation. ${ }^{99}$ A federal statute that eased the budgetary pressures imposed on local governments by national inflation for

97. Id.

98. See PETERSON, supra note 25, at 28:

[S]tates and localities cannot regulate the money supply. If unemployment is low, they cannot stimulate the economy by increasing the monetary flow. If inflationary pressures adversely affect their competitive edge in the export market, localities can neither restrict the money supply nor directly control prices and wages. All of these powers are reserved for national governments.

99. It is somewhat difficult to articulate a localist argument in favor of the federal statute at issue in National League of Cities. The statute imposed severe financial burdens on state and local governmental service providers and appeared to do little to enhance their powers to provide such services. Nat'l League of Cities, 426 U.S. at 846-51. There certainly were not tangible, negative extralocal externalities to which the federal legislation might have been responding. Moreover, the interstate competition for labor in the private market would not appear to be nearly so pressing in the market for public employees. A claim for federal intervention would therefore depend upon classic arguments for national power. The localist argument for applying the statute to local (as opposed to state) governments is somewhat stronger. For example, local governments might pay lower wages to public employees than their residents might prefer, all things considered, because of state law constraints on their revenue-raising powers, such as state law limits on their taxing power. Or local governments might keep wages low because of a concern that increasing local taxes to pay higher wages will hurt them in the competition with neighboring localities for taxpayers. In this respect, the federal statute might be responding to extralocal constraints on local discretion; it establishes a uniform minimum pay scale that frees localities wishing to pay higher wages to their employees from the potential loss in residents that could follow in the absence of such federal intervention. An argument along these lines would not explain, however, why the federal government should be permitted to promote local governmental autonomy at the expense of state governmental autonomy. $C f$. Lawrence County v. Lead-Deadwood Sch. Dist., 469 U.S. 256, 270 (1985) (invalidating, as preempted, a state law that required a county to disburse to a school district a portion of the federal funds that it had received pursuant to a federal statute). The state itself could impose a uniform rule if it wanted to free some of its local jurisdictions from the constraints imposed by such interlocal competition for taxpayers. Cf. City of La Grande v. Pub. Employe[e]s Ret. Bd., 576 P.2d 1204, 1205 (1978) (upholding a state law affecting salaries of local governmental employees against a state constitutional home rule challenge). 
this reason stood on a different footing than federal legislation that would have increased those same budgetary pressures.

The recognition of a substantive, material, or descriptive conception of local autonomy denaturalizes local power. It presents local autonomy as a positive right to something-the enhancement of the local capacity to provide governmental services-rather than a negative right from something-visible centralized lawmaking. Indeed, the Court's focus on the importance of protecting the provision of important local governmental services from infringement led some hopeful commentators to see the decision as a potential source of federal constitutional welfare rights. ${ }^{100}$ On this view, the decision in National League of Cities rested on a conception of the federal system in which citizens had a right to expect the delivery of integral services at the local level. That this right was sufficiently strong to preclude federal impairment suggested that the right itself had a constitutional grounding in the individual rights provisions of the federal Constitution. That being the case, then perhaps Congress, or the courts, could intervene to compel the provision of such local services in the face of evidence that localities were failing to carry out such functions. ${ }^{101}$

A constitutional interest in protecting the local provision of public services would in this way operate not only as a shield against federal legislation that threatened to obstruct the delivery of such services but also as a sword to compel their delivery. Such readings of National League of Cities, albeit inaccurate predictions about where doctrine was headed, show the ways in which an activist vision of federal government could be reconciled with a decision that emphasized the importance of the local provision of governmental services. Such

100. See generally Frank I. Michelman, States' Rights and States' Roles: Permutations of "Sovereignty" in National League of Cities v. Usery, 86 YALE L.J. 1165, 1172 (1977) ("[I]n holding that the [Fair Labor Standards Act] amendments (especially as applied to municipalities) impinged upon state sovereignty, the Court ... was using 'sovereignty' to stand-rather unexpectedly - for ... the state's role of providing for the interests of its citizens in receiving important social services."); Laurence H. Tribe, Unraveling National League of Cities: The New Federalism and Affirmative Rights to Essential Government Services, 90 HARV. L. REV. 1065, 1102 (1977) ("[W]e must recognize in the Court's concern for federalism a fear that, if state decisionmaking and the demands on state budgets are not sufficiently respected, certain individual rights to decent levels of basic government services ... might not be met.").

101. See Michelman, supra note 100, at 1191 ("[J]udicial incapacity, without legislative assistance, to give ... effect to certain inchoate rights does not imply judicial incapacity to seize upon political actions that are visibly responsive to those inchoate rights ...."); Tribe, supra note 100, at 1074-75 (discussing the potential conflicts that might arise between state governments and the federal government upon the latter's insistence that the former use its own funds to support social services). 
readings of the case sought to discern a shift in the background understanding of what federal law required of local governmental institutions. They took the Court's defense of local autonomy to rest less in an inherent right to pay lower wages to governmental employees than in an inherent obligation to provide important services at the local level. In so reading the decision, these commentators made nationalism and localism less inevitable rivals for authority than potential allies in the task of improving the capacity of localities to supply services to their residents.

As is well known, the Court eventually overruled the National League of Cities decision in Garcia v. San Antonio Metropolitan Transit Authority. ${ }^{102}$ There things stood until the revival of federalism began with the Court's decisions, first in New York v. United States ${ }^{103}$ and later, and more significantly, in United States v. Lopez, ${ }^{104}$ Printz v. United States, ${ }^{105}$ and United States v. Morrison. ${ }^{106}$ The new federalism revival does not purport to reinstate the doctrine that National League of Cities sought to establish, and it is not easy to find a current defender of the National League of Cities approach to federalism. Few now clamor for a return to a balancing test in federalism jurisprudence or for a renewed effort to define categories of traditionally governmental activities in which Congress may not interfere even when operating pursuant to an enumerated power. Indeed, even Justice Blackmun, who provided the tie-breaking vote in National League of Cities, was moved to declare the National League of Cities enterprise "unworkable" in Garcia. ${ }^{107}$

But these concerns relate primarily to how National League of Cities addressed the question of when an overriding national interest should suffice to trump a localist interest. If we leave that issue aside it still is noteworthy that the Court seemed aware that federal statutes might ease local pressures. We ordinarily think of National League of Cities as a case that paradigmatically treats the local realm as a separate island that must be insulated from central commands for the sake of protecting local autonomy. Yet one finds within it the pull of a more substantive, material, or descriptive notion of local autonomy,

\footnotetext{
102. 469 U.S. 528,531 (1985).

103. 505 U.S. 144 (1992).

104. 514 U.S. 549 (1995).

105. 521 U.S. 898 (1997).

106. 529 U.S. 598 (2000).

107. Garcia, 469 U.S. at 531.
} 
rooted in a recognition that localities exist within a larger, coordinated structure and depend at all times upon central law for their autonomy. With this latter understanding in mind, the central government no longer appears as an inevitable threat to the protection of local autonomy. It stands as an important protector of it.

\section{B. The New Federalism Revival}

The new federalism revival has a different character. The current Court has not recognized the ways that seemingly anti-local central intervention actually might promote local autonomy. It simply appeals to the imperative of protecting "local autonomy" in issuing decisions that, by constraining central power, actually may restrict local autonomy. That is not to say that the Court's decisions are necessarily incorrect as a matter of constitutional law. It may be that such decisions can be defended on grounds of constitutional history or text. It does mean, however, that the Court's decisions should not be praised as a useful means of promoting the benefits commonly associated with localism. No such normative defense should be available because, by failing to attend to the baseline problem, the Court may have done much to hamper the central government's capacity to promote those very benefits.

The Court's recent decisions set forth two important federalismbased limits on federal power: external constraints on congressional power and internal ones. External constraints are those that arise from the Tenth Amendment or structural features of the Constitution; internal ones are those that are embedded within the clauses that grant enumerated powers to the national government.

1. External Constraints. The anticommandeering cases, Printz $v$. United States and New York v. United States, set forth a key external limitation on congressional power to regulate even matters that clearly affect interstate commerce. ${ }^{108}$ Although the limitation has been

108. Another important set of recent cases that set forth external constraints on congressional power are those concerning state sovereign immunity. They bar Congress from authorizing private damages actions against states-authorization that would abrogate the sovereign immunity states would otherwise be entitled to assert against such actions. See, e.g., Alden v. Maine, 527 U.S. 706, 712 (1999) (holding that Congress had no constitutional authority to authorize private actions against a nonconsenting state in its own courts through the Fair Labor Standards Act); Seminole Tribe v. Florida, 517 U.S. 44, 47 (1996) (holding that Congress had no constitutional authority to authorize Native Americans to bring suit against a nonconsenting state in federal court pursuant to the Indian Gaming Regulatory Act). Insofar as these cases 
criticized from many perspectives, even the critics assume that the limitation protects local autonomy. ${ }^{109}$ Viewed from the more compli-

emphasize the importance of protecting state treasuries from the uncertain consequences that would follow from private suits, they might be understood to resonate quite strongly with the Court's holding in National League of Cities. In both instances, the Court limits federal power to protect more local governmental decisionmakers from federally imposed budgetary pressures that will have direct operational impacts on efficacious local service delivery. It is difficult to construct a localist argument for permitting such federally authorized liability judgments. A defense of them would have to proceed, therefore, on centralist grounds that emphasize the problems with respecting local decisionmaking discretion. On the other hand, it may be the sovereign immunity cases simply bespeak a formal judgment about the kind of autonomy that sovereignty demands apart from its operational effects on actual local decisionmaking power. That is so because the operational impacts of private damages actions on local power do not seem to be at all central to the Court's recent sovereign immunity decisions. It is the importance of protecting the state from federal intervention-abstracted from any more practical inquirythat animates them. Indeed, precisely for that reason, the decisions hold that Congress may not authorize even injunctive actions that name the state as the defendant. Alabama v. Pugh, 438 U.S. 781, 782 (1978) (per curiam). They also hold that local governments are categorically exempted from the protections afforded their states by this strain of doctrine-an exemption that obviously has no logic from the localist perspective that animates the National League of Cities decision. See generally Lincoln County v. Luning, 133 U.S. 529, 530 (1890) (holding that the Eleventh Amendment does not preclude the bringing of private suits against counties). In this respect, it is as if the limitation on the federal power to make states suable is itself understood to be constitutive of a legal system that is properly respectful of local power. The localist interest is articulated in significant part as a negative limitation on central power.

109. See, e.g., Matthew Adler \& Seth Kreimer, The New Etiquette of Federalism: New York, Printz, and Yeskey, 1998 SUP. CT. REV. 71, 142-43 (assuming that commandeering would limit local autonomy but criticizing the anticommandeering rule nonetheless); Evan Caminker, Printz, State Sovereignty and the Limits of Formalism, 1997 SUP. CT. REV. 199, 206-33 (assuming that federal commandeering would infringe local autonomy but questioning the Court's conclusion that the Constitution protects local autonomy from such intrusion). These critics support their argument by pointing to the range of arguably more intrusive alternatives that are left to the federal government notwithstanding the ban on commandeering. Adler \& Kreimer, supra, at 83-119; Caminker, supra, at 233-43. They have argued that it is an odd defense of local autonomy that encourages the federal government to achieve its ends through more intrusive measures such as the use of federal agents, Caminker, supra, at 226-29, 237, or broader federal preemption, Adler \& Kreimer, supra, at 83-89, 95-101. See also LAURENCE TrIBE, AMERICAN CONSTITUTIONAL LAW 891 (3d ed. 2000) (noting that the Supreme Court's non-balancing approach in Printz "seems troublesome" to the extent that it fails to answer the challenge that allowing Congress to do "a little conscripting of state officials" can be more federalism-friendly than having "a vast federal army of bureaucrats administer a federal program" in some circumstances). This line of criticism appears to assume, however, that the total absence of federal intervention would be most protective of local autonomy and certainly more protective than a federal statute that commandeered state officials. The argument presented in this Essay, by contrast, emphasizes the way an absence of federal intervention-whether such intervention would take the form of a federal command to states to perform background checks, a federal regime that established a federal bureaucracy to perform such checks, or a preemptive federal law-also would constrain local autonomy. The anticommandeering rule constitutes a constraint on local autonomy, on this view, precisely because the alternatives to commandeering that the federal government retains are, in fact, less effective tools for responding to interlocal negative externalities than is a federal command to state and local agents. For the argument in this re- 
cated localist perspective suggested above, it is not clear that this assumption is accurate. In Printz, the Supreme Court held that a constitutional principle of federalism, apparently external to Congress's power to regulate commercial activity, invalidated a statute that would have required local law enforcement officers to perform background checks of gun buyers. ${ }^{110}$ The Court held that the statute impermissibly commandeered local governmental officers to administer a federal regulatory program. ${ }^{111}$ Defenders of federalism are likely to see such a decision as a salutary defense of local against central power, ${ }^{112}$ and, indeed, the Court itself suggested that it was engaged in the task of ensuring just such protection. ${ }^{113}$

The decision appears to free each locality to decide for itself whether to perform such checks. Rather than being made puppets of the federal government, state and local law enforcement officers retain their autonomy to allocate their time and resources as they choose. The decision therefore might seem to be in accord with that in National League of Cities. Just as the federal statute in that case imposed costs on local service delivery, in the form of mandates to provide higher wages, the federal statute in this case imposed costs on local service delivery, in the form of mandates to perform certain time-consuming tasks - namely background checks.

But the federal statute invalidated in Printz did more than simply limit the discretion of local law enforcement officers to decline to perform background checks. It also would have relieved many local law enforcement agents of the burdens imposed upon them by the prior absence of the federal command. The federal statute can be seen as an effort to protect localities from the negative externalities created by the operation of gun markets in neighboring jurisdictions with comparatively lax gun control policies. Indeed, evidence suggests that the primary benefit of a federally mandated background-check system would be to curtail the influx of guns into states with strong gun laws from states that require no background check. ${ }^{114}$ Absent a federal

\footnotetext{
gard, see infra notes $114-16$ and accompanying text.

110. Printz, 521 U.S. at 935.

111. $I d$.

112. See generally Roderick M. Hills, Jr., The Political Economy of Cooperative Federalism: Why State Autonomy Makes Sense and "Dual Sovereignty” Doesn't, 96 Mich. L. REv. 813 (1998) (emphasizing the autonomy that states obtain from the anticommandeering rule).

113. See Printz, 521 U.S. at 935 (stating that "such commands [by the federal government] are fundamentally incompatible with our constitutional system of dual sovereignty").

114. Brady Campaign to Prevent Gun Violence, Traffic Stop: How the Brady Act Disrupts
} 
requirement that background checks be conducted, some local law enforcement agents spend time investigating gun crimes committed with out-of-state guns that otherwise would have been devoted to other local matters. A local jurisdiction easily could see the Printz decision, therefore, as a threat to its local autonomy. The fact that central law does not require gun markets to be jurisdictionally bounded no doubt explains why the United States Conference of Mayors weighed in on the side of the federal government in the case. ${ }^{115}$ For the Conference, meaningful local control required federal intervention that would allow localities to control the availability of guns within their boundaries so that they could pursue other policies that gun violence frustrated. ${ }^{116}$

This defense is no less localist than the argument offered by opponents of the federal command. It, too, emphasizes the importance of protecting local "autonomy" from external forces. It recognizes, however, that the burdens that local jurisdictions impose upon one another, by virtue of their proximity, complicate what "autonomy" means. The federal statute at issue in Printz altered the baseline distribution of power between local governments. The statute did not simply limit the capacity of local governments to determine how such services should be provided. Why, then, should we see the statute invalidated in Printz as interfering with local control? Why not see it, like the Economic Stabilization Act upheld in National League of Cities, as a case of federal intervention that promotes local control?

One might object that the prohibition against federal commandeering simply requires the federal government to respond through other, less intrusive means to the negative externalities imposed by some states on others. ${ }^{117}$ It is a mistake to credit this objection. None

Interstate Gun Trafficking, Executive Summary, at http://www.bradycampaign.org/facts/research/ traffic.asp (Aug. 22, 2001) (on file with the Duke Law Journal).

115. Brief of Amici Curiae Handgun Control, Inc. et al. at 1, Printz v. United States, 521 U.S. 898 (1997) (Nos. 95-1478, 95-1503).

116. Indeed, many local jurisdictions eager to keep guns out of their locales have asserted their power to sue gun manufacturers for flooding gun markets in jurisdictions that have lax gun laws. See David Kairys, The Origins and Development of the Governmental Handgun Cases, 32 CONN. L. REV. 1163, 1171-72 (2000) (discussing the suits as a response, in part, to the problem of crimes being committed with out-of-state guns). The authority to bring such suits is defended on what are easily understood as localist grounds. See Brent W. Landau, State Bans on City Gun Lawsuits, 37 HARV. J. ON LEGIS. 623, 638 (2000) (arguing in favor of the right of cities to sue the gun industry to reduce gun violence and to recover from losses suffered from such violence).

117. For example, even after Printz, the federal government may respond by directly preempting the sale of guns without background checks, thereby leaving it to local discretion whether to supply such checks. Or it may establish its own federal bureaucracy for carrying out 
of the alternatives may be as useful a tool in responding to negative externalities. ${ }^{118}$ Because each alternative is a less effective means of protecting jurisdictions burdened by extralocal gun markets, the anticommandeering rule substantively limits the federal government's capacity to respond to negative externalities. As a result, the argument that an anticommandeering rule protects state autonomy by granting states an entitlement that they may deploy against the federal government is quite problematic. In a case like Printz, the entitlement may empower those states that are lax in policing gun sales but, at the same time, it disempowers those states that are suffering the negative externalities caused by such lax gun policies. Hence, the key question in a case like Printz is not whether the states as a whole should have an entitlement against the federal government, but whether some states should be benefited through the conferral of such an entitlement over other states. Central law necessarily answers that question in every case. The intuitive notion that freedom from

the background checks. Or it may use the spending power to encourage compliance. Or, finally, it may authorize states to exclude out-of-state guns that were sold without background checks.

118. The anticommandeering rule applies even when, as in Printz, there is no dispute that the federal command must be obeyed only during the period in which a federal bureaucracy is made operable. As a result, the anticommandeering rule effectively requires localities to bear the costs imposed by their neighbors during the interim period in which no federal bureaucracy plausibly could be established. Similarly, a federal law that bans all gun sales except those that have been made after a background check (without supplying a federal regime for such checks or compelling states to provide them) establishes in unprecedented fashion a baseline legal regime that makes all gun sales presumptively unlawful under federal law. The sweeping nature of such a measure makes it much less likely to be adopted than a statute that mandates background checks and thereby does not contemplate the possibility that gun sales could be banned entirely as a matter of federal law. The fact that Congress may induce state and local governmental compliance, consistent with the anticommandeering rule, through spending measures is also not significant. Insofar as the Spending Clause can be used as a means of coercing compliance, then it seems to be no different than a command, and insofar as it cannot, it leaves vulnerable the localities that would be subject to the costs imposed by those localities who reject the funding. If the objection is just to the lack of a federal payment for the costs of complying with the federal command, then the rule could be formulated to prohibit unfunded, but not funded, mandates. But that would suggest that the objection to federal commandeering is not really to commandeering per se but rather to the regulatory costs that federal intervention may impose upon nonconsenting states. Yet compliance costs are imposed even in cases of ordinary preemption, so unless one wants to require the federal government to pay any time it imposes compliance costs, the distinction between funded and unfunded commands seems unhelpful. Finally, a federal statute that authorized states to prohibit the entry of out-of-state guns sold without background checks would not be an effective substitute for the federal command struck down in Printz. Such a statute would require those states seeking to exclude such guns to bear the costs of maintaining the barrier to entry. The federal commandeering statute, by contrast, makes each jurisdiction responsible for performing the checks in its own states. 
central command protects local autonomy obscures the way in which a central law may (re)distribute local autonomy.

Consider another commandeering case in which the relationship between local autonomy and central intervention is more complicated than the Court acknowledges. New York v. United States, ${ }^{119}$ the precursor to Printz, concerned the constitutionality of certain provisions of the Low-Level Radioactive Waste Policy Amendments of $1985 .^{120}$ New York contended that it had no responsibility for the disposal of the privately generated waste within its borders_-indeed, that it could refuse to permit private actors to store locally generated waste within the state's borders-and that the federal government could not impose such a responsibility upon it. ${ }^{121}$ It therefore argued that the federal government had no constitutional power to command it to take such responsibility by putting it to the "choice" of two coercive options: "take title" to all waste generated-even if by private partieswithin its borders or otherwise enact a program for disposing of locally generated waste. ${ }^{122}$ The Court ruled for New York in order to protect its autonomy from a central command. ${ }^{123}$

The ruling obscures the fact that the federal command had been enacted as a response to less visible, preexisting federal constraints. Under the federal Constitution, states may not, unless expressly authorized by federal statute, establish interstate compacts to dispose of waste, nor enact protectionist legislation discriminating against out-of-state waste. ${ }^{124}$ Many states in the years prior to the enactment of the statutory framework at issue in New York took advantage of these rules and declined to approve their own waste disposal sites. ${ }^{125}$ The few states that had approved disposal sites thus were fast becoming home to huge amounts of out-of-state waste. The sited states eventually threatened to get out of the waste disposal business altogether; given background federal law, they had no other means of avoiding becoming the dumping ground for the bulk of the nation's hazardous waste. ${ }^{126}$ Had they shut down the sites in their states, there

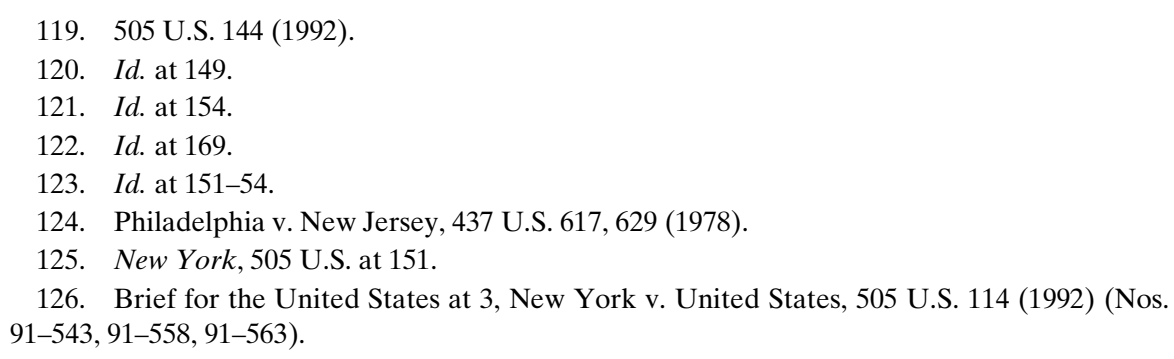


would have been a real risk that no sites would be available for disposing of hazardous waste. In that event, the federal government (as well as the states themselves) would have been forced to tolerate the shutting down of waste-generating industries-hardly a tolerable option. Or, to avoid such an occurrence, the federal government would have been forced to establish its own disposal sites within certain states (thereby ousting states of any real say over the siting process). ${ }^{127}$

In the face of this looming crisis, the states collectively proposed to Congress a complex federal statutory framework. ${ }^{128}$ The proposal sought to ensure that states would retain control over the siting process and that the federal government would not assume power over siting decisions. ${ }^{129}$ It also sought to ensure that the sited states would not become national dumping grounds. ${ }^{130}$ The proposed framework, as enacted, authorized the states to enter into regional compacts with other states for waste disposal and to impose otherwise impermissibly discriminatory surcharges on waste from states not part of a compact for a period of years. ${ }^{131}$ The framework further authorized sited states, and those in compact with them, to deny access outright to nonmember states after that statutorily prescribed period of years had ended. ${ }^{132}$ Only then would states that continued to generate waste but had not entered into a compact be required to take title to the waste generated in their jurisdiction or otherwise establish a means of disposing of such waste. ${ }^{133}$

As the sited states explained in their amicus brief to the Supreme Court, the supposedly "coercive" provisions had been critical to the success of the entire, state-friendly federal framework. ${ }^{134}$ The provisions induced states to enter into compacts rather than bet that enough of them would hold out to precipitate a crisis that would occasion wholesale federal intervention, which would result in states los-

127. Id. at 4; Brief for States of Washington, Nevada and South Carolina at 2-10, New York v. United States, 505 U.S. 114 (1992) (Nos. 91-543, 91-558, 91-563) (recounting the history of the crisis).

128. New York, 505 U.S. at 151.

129. Brief for States of Washington, Nevada and South Carolina at 8-9, New York (Nos. 91$543,91-558,91-563)$.

130. Id. at 12 .

131. New York, 505 U.S. at 151-52.

132. Id. at 152 .

133. Brief for the United States at 13, New York (Nos. 91-543, 91-558, 91-563).

134. Brief for States of Washington, Nevada and South Carolina at 4-9, New York (Nos. 91$543,91-558,91-563$ ) (describing how the states acted in the interest of federalism to avoid a national solution to the problem). 
ing control of the siting process. ${ }^{135}$ Indeed, a prior state-proposed federal framework that did not include the "take title" provisions had failed to induce enough states to enter into regional compacts to ensure that sufficient waste disposal sites would be available for wastegenerators. As a result, Congress simply had extended the time during which the sited states would have to take in out-of-state waste, thereby imposing the costs of choices by recalcitrant states on neighbors. ${ }^{136}$ In this way, a legal regime that relied ultimately on federal preemption (rather than individual state responsibility) for the disposal of locally generated waste threatened to subject some states to harms beyond their control. The coercive "take title" provisions, from this perspective, mitigated that threat.

Prior to the adoption of the coercive federal statute there was already a federal law regime in place that constrained state autonomy. That regime entitled some states to take no responsibility for-and, indeed, even to preclude private actors from assuming responsibility for-disposing of the waste that they chose to permit industries within their borders to generate. That regime was not obviously more respectful of state power than the regime that the federal statute sought to bring into place. Congress, in deciding how to respond to the waste disposal crisis, was therefore called upon to make a number of policy decisions about what kind of state autonomy it should promote. Should it protect the power of states to exclude out-of-state waste or should it protect the power of states to compel the export of in-state waste? Should it secure the power of states to make decisions about whether to provide for the disposal of waste that they had permitted to be generated within their borders, or should it instead take account of how one state's decision to decline to provide for such disposal would impact the discretion of neighboring states? Should it, in short, treat a state's decision to provide no means of disposing of locally generated waste as an expression of local autonomy or as a threat to the autonomy of neighbors? In making these judgments, the national government was not clearly choosing whether to trump local autonomy in the name of vindicating some higher, national objective. Nor was it, in enacting seemingly "coercive" measures, choosing to disregard the autonomy of the states. It was instead attempting to craft a

135. Id.

136. Id. at 25 (recounting the burdens incurred by the sited states as a result of the extension Congress granted). 
solution to an interstate problem in which there was no clear baseline from which a claim for local autonomy could proceed.

In this regard, it is problematic to argue that the anticommandeering rule respects a state's right not to be "used" by the federal government as if it were a mere extension of the national legislature. New York was mandated, in effect, to take responsibility for the disposal of that waste generated within its borders. It is not evident that a national legal judgment that a state is responsible for disposing ofor providing a means for disposing of-those dangerous substances generated within its borders makes a state the mere extension of the federal sovereign's will. Unless one can explain persuasively why a state's autonomy depends upon its power to choose to take no responsibility for the waste that it voluntarily permits industries within its borders to generate (and thus to shift the costs of such a choice onto neighboring states), the claim that a state has been "used" by being made responsible for such a choice has a hollow ring. One could conclude just as easily that the prior legal regime permitted New York to "use" the sited states. Thus, the argument for the exercise of national power in a case like New York is itself localist. It seeks to promote the capacity of local jurisdictions to make their own judgments for the very reasons commonly thought to justify decentralized decisionmaking. It does not depend on a defense of an overriding national judgment as to how waste should be disposed of locally. $^{137}$

2. Internal Constraints. Evidence of a similarly problematic approach to central-local relations may be discerned in the cases that make up perhaps the most dramatic aspect of the recent federalism revival - cases that identify internal constraints on the clauses of the

137. It is true that Congress retained the power to threaten to preempt state siting decisions in the event that states failed to dispose of waste on their own or to enter into compacts with other sited states. See New York v. United States, 505 U.S. 144, 167 (1992) (“[W]here Congress has the authority to regulate private activity under the Commerce Clause, we have recognized Congress' power to offer States the choice of regulating that activity according to federal standards or having state law pre-empted by federal regulation."). But the States' own fear of giving up control of the siting process to the federal government had led them to propose a framework in which that option would not be available. See Brief for States of Washington, Nevada and South Carolina at 12-15, New York (Nos. 91-543, 91-558, 91-563) ("Each state . . . asked Congress to defer to the states' sovereign desire to be responsible for low-level radioactive waste generated within their respective borders."). And the difficulties of bringing about such federal preemption was sure to extend the time during which the sited states would have to bear the costs of their neighbors in order to avert a crisis that would result in the shutting down of vital industries in neighboring states on which they, too, depended. 
Constitution that grant power to Congress. There are two sets of relevant cases here: those relying on internal constraints to limit the power of Congress to exercise its commerce authority and those relying on internal constraints to limit the power of Congress to legislate pursuant to the enforcement clause of the Fourteenth Amendment. For present purposes, it is sufficient to consider in detail only the former line of precedent, though there is an important resonance between the two. ${ }^{13}$

The first of the cases that place internal constraints on congressional commerce authority in order to protect local power is United States v. Lopez. ${ }^{139}$ The case concerned whether Congress possessed authority under the Commerce Clause to make it a criminal offense to possess a firearm within one thousand feet of a school. ${ }^{140}$ The main opinion, authored by Chief Justice Rehnquist, held that it did not. ${ }^{141}$ The opinion noted that the Commerce Clause only empowers Congress to regulate commerce among the states, and that the statutory provision at issue did not appear to regulate commercial activity at

138. The Section 5 cases in general concern federal statutes that are designed to abrogate the state sovereign immunity recognized by the Court as constitutionally ordained in the cases already discussed. In this sense, they are derivative of the localist vision that underlies those decisions. See, e.g., Kimel v. Fla. Bd. of Regents, 528 U.S. 62, 64 (2000) (holding invalid, under Section 5 of the Fourteenth Amendment, Congress's intent to abrogate the states' sovereign immunity through the Age Discrimination in Employment Act); Fla. Prepaid Postsecondary Educ. Expense Bd. v. College Sav. Bank, 527 U.S. 627, 630 (1999) (holding invalid, under Section 5 of the Fourteenth Amendment, Congress's intent to abrogate the states' sovereign immunity through a series of patent law amendments). Two important exceptions, however, concern City of Boerne v. Flores, 521 U.S. 507 (1997), and United States v. Morrison, 529 U.S. 598 (2000). The Section 5 analysis in Morrison turned largely on the question of what constitutes "state action," because the federal remedy ran against a private party rather than the government, and thus it did not implicate directly concerns about protecting local from state power. 529 U.S. at 619-27. City of Boerne stands as a possible exception to the current Court's general disinterest in examining the impacts of federal legislation on local service delivery. See 521 U.S. at 532 (noting that the Religious Freedom Restoration Act would intrude "at every level of government" due to its sweeping coverage). At the same time, it is not clear that these decisions are driven purely by a localist concern as opposed to a deeper concern about the propriety of congressional, as opposed to judicial, constitutional interpretation. See TRIBE, supra note 109, at 949 n.121 (discussing the extent of Congress's authority to interpret the provisions of the Bill of Rights in a situation in which institutional constraints led the courts to adopt a less intrusive interpretation from among those textually and historically plausible options); Michael W. McConnell, Comment, Institutions and Interpretations: A Critique of City of Boerne v. Flores, 111 HARV. L. REV. 153, 153-57 (1997) (characterizing Boerne as involving a clash over the relationship between congressional and judicial authority to interpret constitutional rights).

139. 514 U.S. 549 (1995).

140. Id. at 551 .

141. Id. 
all. ${ }^{142}$ The Court offered a functional reason for obeying that limitation. Such obeisance will ensure that the Court will not permit the federal government to "obliterate the distinction between what is national and what is local, and create a completely centralized government.","143

In rejecting the federal government's contention that the target of federal laws-here gun possession near a school-need not be commercial activity in order for Congress to regulate it, the Court elaborated on the connection between limiting Congress's commerce power and local autonomy. The Court held that the United States's position would permit Congress to regulate all violent crime or activity that might lead to violent crime. ${ }^{144}$ And why might that be problematic? If the government need only show that its regulation is necessary to protect national economic productivity, then it arguably could regulate "family law (including marriage, divorce, and child custody)." federal power, even in areas such as criminal law enforcement or education where States historically have been sovereign." "The opinion concluded by stating that unless the line is held here "there never will be a distinction between what is truly national and what is truly local. ${ }^{, 147}$

Justice Kennedy's concurrence, which Justice O'Connor joined, showed signs of a more complicated conception of local autonomy. The concurrence inquired into the actual effects of the federal legislation on the capacity of local jurisdictions to make independent judgments as to how to respond to the problem of guns near schools. In doing so, it implicitly acknowledges that federal legislation might facilitate state and local policymaking rather than simply stifling it. It therefore harkens back to the distinction drawn in National League of Cities between a federal command that drains resources from localities and one that eases the resource pressures they would face in the absence of federal intervention.

142. Id. at 559-67.

143. Id. at 557 (quoting NLRB v. Jones \& Laughlin Steel Corp., 301 U.S. 1, 37 (1937)).

144. Id. at 564 .

145. Id.

146. Id. (emphasis added).

147. Id. at 567-68. 
Justice Kennedy explained that, at least in instances where Congress seeks to target noncommercial activity, ${ }^{148}$ "we must inquire whether the exercise of national power seeks to intrude upon an area of traditional state concern." ${ }^{, 149}$ Here, Kennedy noted that "it is well established that education is a traditional concern of the States." ${ }^{150}$ As a result, he explained that there is "a particular duty to ensure that the federal-state balance is not destroyed."

As Justice Kennedy recounted the nature of the central-local clash, he saw evidence that the exercise of federal power would interfere with local policymaking with respect to education. He acknowledged that few states would adopt a policy favoring the carrying of firearms in or near schools, but contended that states might disagree as to whether criminalizing gun possession near schools is an effective means of addressing the problem. ${ }^{152} \mathrm{He}$ noted that alternative approaches could include amnesty programs, the imposition of penalties on parents or guardians rather than on child gun possessors directly, or programs for expelling students carrying such weapons that would send offenders to special facilities rather than prisons. ${ }^{153}$ He suggested that central authority is problematic because of the limits that federal power places on the capacity of local actors to respond to an acknowledged problem-guns in and near schools. ${ }^{154}$ He concluded that the federal criminal statute "forecloses the States from experimenting and exercising their own judgment in an area to which States lay claim by right of history and expertise." 155

Whether or not the concurrence's examination of the effects of the federal legislation on local discretion is persuasive, ${ }^{156}$ the signifi-

148. Id. at 577 (Kennedy, J., concurring) ("Were the Federal Government to take over the regulation of entire areas of traditional state concern, areas having nothing to do with the regulation of commercial activities, the boundaries between the spheres of federal and state authority would blur and political responsibility would become illusory.").

149. Id. at 580 .

150. Id.

151. Id. at 581.

152. Id.

153. Id. at 582.

154. Id. at $581-82$.

155. Id. at 583.

156. It is a potentially awkward argument in light of the concession that forty states have adopted criminal provisions of their own that are analogous and that would seem equally to foreclose the kinds of experimental approaches that he advocates. There is no indication that Justice Kennedy means to suggest that the federal criminal legislation of this kind would be invalid only in states that had no parallel state law criminal statutes. The contention is potentially problematic, given the fact that the federal statute does not of its own force compel prosecutions 
cant point is that the concurrence, unlike the majority opinion, does not view the extension of federal legislation into a realm traditionally policed locally as dispositive. Further inquiry into the effects of the federal legislation on local decisionmaking remains appropriate. In this sense, the analysis is driven by an affirmative vision of local autonomy-and a willingness to examine the way national power might aid local action-rather than a negative aversion to central intervention.

United States v. Morrison, ${ }^{157}$ the next decision of the Court to place an internal limitation on the scope of the federal commerce power, did not pursue this more complex approach. Morrison invalidated a provision of the Violence Against Women Act that provided victims a civil remedy against perpetrators of gender-motivated violence. ${ }^{158}$ As in Lopez, the Court decided that the statute impermissibly extended the federal regulatory sphere to include noncommercial action. ${ }^{159}$ In doing so, the Court did not mention the quasi-balancing test to which Justice Kennedy had been attracted in Lopez. The Court instead adopted a virtually categorical approach. It drew a sharp line between commercial and noncommercial activity in order to preserve traditional state and local governmental functions, without regard to the particularized effect that the federal legislation might have on the carrying out of such functions. ${ }^{160}$

Noting the noncommercial nature of the violent criminal activity targeted by the federal civil remedy, the Court concluded that "the concern that we expressed in Lopez that Congress might use the Commerce Clause to completely obliterate the Constitution's distinction between national and local authority seems well founded." ${ }^{161}$ "[T]he suppression of [violence] has always been the prime object of the States' police power," the Court emphasized. ${ }^{162}$ The federal government's defense of the statute would have permitted the Congress

\footnotetext{
in every case; presumably, United States Attorneys, who are operating at the local level after all, retain the traditional prosecutorial discretion to bring cases in a manner that will not impede effective means of reducing gun possession near schools. See generally Michael Simons, Prosecutorial Discretion and Prosecution Guidelines: A Case Study in Controlling Federalization, 75 N.Y.U. L. REV. 893 (2000) (discussing the role of federal prosecutorial discretion in vindicating federalism values).

157. 529 U.S. 598 (2000).

158. Id. at 602 .

159. Id. at 627.

160. Id. at 615 .

161. Id.

162. Id.
} 
"to regulate murder or any type of violence since gender-motivated violence, as a subset of all violent crime, is certain to have lesser economic impacts than the larger class of which it is a part." ${ }^{, 163}$ To emphasize its concern that the breach of the commercial/noncommercial distinction would threaten local power, the Court explained that “[p]etitioners' reasoning... may ... be applied equally as well to family law and other areas of traditional state regulation since the aggregate effect of marriage, divorce, and childrearing on the national economy is undoubtedly significant." Congress's commerce power is impermissible because "[t]he Constitution requires a distinction between what is truly national and what is truly local." 165

In Lopez, the dissenters had emphasized the plausible connection between gun possession and interstate commerce. ${ }^{166}$ In Morrison, they now concluded that the desire to preserve a distinct domain of local authority, and not simply a skepticism about what substantially affects interstate commercial activity, motivated the Court's newfound interest in delimiting bounds to the commerce power. As Justice Souter put it:

If we now ask why the formalistic economic/noneconomic distinction might matter today ... the answer is not that the majority fails to see causal connections in an integrated economic world. The answer is that in the minds of the majority there is a new animating theory that makes categorical formalism seem useful again. Just as the old formalism had value in the service of an economic conception, the new one is useful in serving a conception of federalism. It is the instrument by which assertions of national power are to be limited in favor of preserving a supposedly discernible, proper sphere of state autonomy to legislate or refrain from legislating as the individual States see fit. ${ }^{167}$

The Morrison dissenters objected not only that the majority overlooked the interconnectedness of modern commercial society, but also that its vision of what it means to protect local control was too limited. In making this point, Justice Souter returned to the dis-

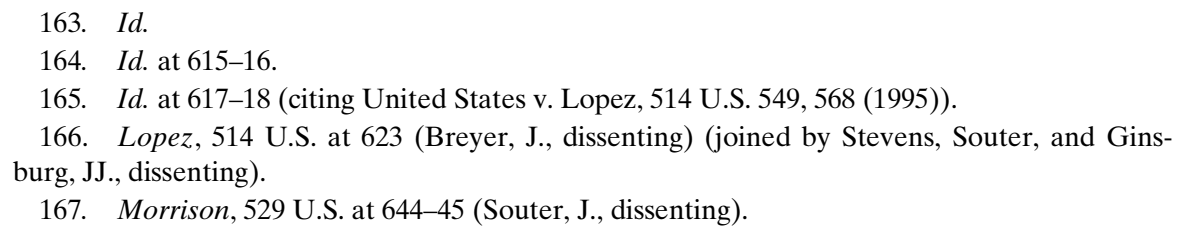


tinction the National League of Cities Court drew between the Fair Labor Standards Act and the Economic Stabilization Act. Justice Souter questioned the majority's assumption that limiting federal power would promote local autonomy, arguing that the majority "finds no significance whatever in the state support for the Act based upon the States' acknowledged failure to deal adequately with gender-based violence in state courts, and the belief of their own law enforcement agencies that national action is essential." ${ }^{168}$ He therefore concluded that "[i]t is, then, not the least irony of these cases that the States will be forced to enjoy the new federalism whether they want it or not." 169

Indeed, the majority of the state attorneys general argued to the Court that, far from limiting the capacity of states to serve their constituents, the federal statute actually enhanced it. As they explained, domestic violence imposed enormous costs on state-delivered welfare and medical services ${ }^{170}$ - services that often were provided only by virtue of the states' need to comply with federal legislation. It was largely states and local governments, therefore, that had to bear the financial burden of such violence, and in large part because of the structure of federal entitlement programs. More fundamentally, the federal remedy supplied by the Violence Against Women Act was, they argued, entirely complementary with ongoing state law reform efforts concerning domestic and gender-motivated violence. ${ }^{171}$ The remedy did not preempt state and local remedies, and it was keyed to a violation of state or local law. ${ }^{172}$ As the brief of the state attorneys general put it, the federal statute supplied a remedy that was useful in the interim while state and local reform efforts began to produce state and local laws regulating violence against women that were similar to the one supplied by the federal statute. ${ }^{173}$ It would free them from budgetary pressures during the reform period-pressures they would

\footnotetext{
168. Id. at 653.

169. Id. at 654 .

170. Brief of Amici Curiae State of Arizona et al. at 9-15, United States v. Morrison, 529 U.S. 598 (2000) (Nos. 99-5, 99-29).

171. Id. at 21-23.

172. See id. at 21 ("The crimes that are actionable under [the Violence Against Women Act's] civil provisions are defined by reference to existing federal and state law.").

173. See id. ("By providing the civil remedy, Congress made it possible for gender-based violence-and its impact on interstate commerce-to be redressed now, while States continue to reform and refine their approaches to this scourge.").
} 
face as a consequence of their obligation to comply with provisions of federal entitlement programs.

There are problems with simply deferring to the argument of the attorneys general. They may not be representative of states' interests, and their characterization of the federal statute as supplemental is, of course, subject to the rejoinder that it was preemptive of those states that already had chosen not to make residents liable for gendermotivated violence through specific tort actions targeting that kind of violence. Precisely because of the difficulty of distinguishing preemptive from supplemental central legislation, however, their argument reveals that more was at stake in Morrison than simply protecting the local sphere from central power. Protecting the local sphere from the national sphere also imposes costs on the local sphere that might have been mitigated by the central law intervention at issue.

\section{Comparing the Old and the New}

National League of Cities' distinction between the Fair Labor Standards Act and the Economic Stabilization Act pushed to the fore questions about what it means to protect local autonomy. It made visible the pressures on local governments that come from sources other than directly preemptive central power. And it suggested a potential distinction between a procedural, formal, or ascriptive idea of local autonomy-in which limiting visible central power is emphasized-and a substantive, material, or descriptive idea of local autonomy-in which the limits on effective decisionmaking capacity imposed by background central laws are emphasized. The current Court's approach, by contrast, suggests that the localist interest can be served simply by limiting visible central power and that the exercise of visible central power that limits the discretion of a local jurisdiction cannot at the same time promote localism. ${ }^{174}$

174. This comparative analysis does not show that National League of Cities is in some objective sense more protective of federal power than the cases that comprise the current federalism revival. The localist vision pursued in National League of Cities, it must be remembered, invalidated the application of the requirements of the Fair Labor Standards Act to state and local governments. Nat'l League of Cities v. Usery, 426 U.S. 833, 855-56 (1976). The current localist vision compels no such result. States remain subject to the commands of the Fair Labor Standards Act under the new regime. Recent developments in the law of sovereign immunity do bar states from being subjected to monetary damages for violating those requirements, but local governments, as has been noted, are not similarly protected. See supra note 108 . They remain subject to damages claims for violating the Act. In this sense, Congress arguably enjoys more authority under the current federalism revival than it did under its predecessor. Nor does this analysis show that Morrison and Lopez have it wrong in their enunciation of internal Commerce 
It is useful in this regard to call attention to the article for this conference by Professors Baker and Young. ${ }^{175}$ Baker and Young attempt to defend the recent federalism revival in negative terms by appealing to the importance of "autonomy," understood as the condition of being free to choose for oneself. In arguing that a defense of states' rights should not be held to account for the content of state decisionmaking, they conclude that a "state's freedom from federal interference, like an individual's freedom from governmental restrictions on expression or private choices, is an essentially negative freedom."

Their emphasis on autonomy, and the negative rights from central interference that it implies, suggests a neutral baseline from which local autonomy can be defended. It naturalizes the legal world that "precedes" central intervention as one respectful of autonomy. It presumes that state and local governments are autonomous prior to visible central lawmaking in the way that many imagine private individuals to be free prior to governmental regulation. Yet Baker and Young implicitly (if unintentionally) acknowledge elsewhere in their argument that this presumption of autonomy is mistaken. In arguing that exercises of central preemptive power often constitute "horizontal aggrandizements" ${ }^{177}$ by some states over others, they necessarily concede that the actions of some localities affect those of others, and that changes in central power distribute, rather than simply infringe, local power. It is that concession that underlies their concern that some states could gain at the expense of others through an exercise of federal law.

It is true that one can always leave a particular locality, as they suggest, while one cannot exit so easily the central system. But the invocation of the right to exit does not thereby reveal central power necessarily to be a threat to local autonomy. Indeed, ironically, the right to exit is itself-as we saw in the context of the New York decision-a background rule of central law that can infringe local autonomy as surely as it can justify its defense. For example, it is precisely because central law usually permits boundaries to be relatively porous-in the New York case permitting companies to exercise "the

Clause limits that track a commercial/noncommercial line. Nothing offered above counts as a sufficient argument about the proper constitutional interpretation of the Commerce Clause.

175. Lynn A. Baker and Ernest A. Young, Federalism and the Double Standard of Judicial Review, 51 DUKE L.J. 75 (2001).

176. Id. at 134.

177. See id. at 117-28. 
right to exit" by shipping their waste out-of-state-that the costs of a "local" policy often are passed on to a neighboring jurisdiction. In other words, central lawmaking of the kind that Baker and Young fear in fact may free (many) local jurisdictions from less visible background constraints that act as real limits on their capacity to "choose." It therefore may vindicate the very values that are said to attach to the protection of local autonomy.

A procedural, formal, or ascriptive defense of local autonomy of the kind Baker and Young offer has little to commend it once its monopolistic claim on the attractive values associated with local autonomy is stripped away. Thus, its proponents must do more than trumpet the importance of keeping states and localities "free" from central interference. They must explain why it makes sense to think of states as free in the first place, and why the kind of freedom they would possess absent visible central intervention is preferable to the kind of freedom that they would possess in its presence. As we have seen, inscribed within such a defense of local autonomy is a particular, but contestable, idea of local autonomy-one that conceives of localities as independent, free islands that must be protected from a leviathan above. But if our concern is not with preserving some imagined zone of preexisting local autonomy from central interference, then it becomes clear that other ideas of local autonomy are available. Such ideas could take the central government's exercise of visible preemptive power to be an important means of promoting local power. For example, the horizontal aggrandizements that Baker and Young fear instead might be reconceived as instances of interlocal collective action that central law can make uniquely possible. If central law wishes to protect localities as if they were islands, then it must resist collective solutions unless they are unanimous, as Baker and Young suggest. But if it wishes to empower localities to overcome the irresponsible actions of holdouts, then it must enact a rule system that permits collective solutions, even though they are not approved unanimously. That is the kind of choice central law faces when it seeks to protect local autonomy. In making that choice, the central government will not unambiguously vindicate local autonomy no matter how it acts; it will infringe it by attempting to promote it or by choosing one idea of local autonomy at the expense of others. But that is inevitably the case when the limits on local power come from some source other than the visible intervention of the central government itself.

At the level of current doctrine, the Court's formal rules categorically proscribing certain means of central intervention are un- 
likely to protect local autonomy in any sense but the ascriptive one. They are ill-suited to distinguish between the two kinds of central lawmaking identified at the outset: those that promote some independent central governmental interest and those that respond to the extralocal pressures that local jurisdictions face even in the absence of direct and visible central intervention.

One might object that the current Court's impulse to fashion a federalism doctrine that has this categorical cast arises from a felt need to ensure that modern doctrine reflects respect for states as independent actors within the constitutional structure. Given the limits of the judicial role, the current Court's approach therefore simply may be an effort to fashion a plausible doctrine to that end. The establishment of clean lines-legislation that preempts state power is permissible, but regulation that commandeers state power to administer federal programs is not; commercial activity may be regulated, but noncommercial activity may not-does overcome the concerns about workability that led Justice Blackmun to abandon the National League of Cities approach in Garcia. The current federalism project might be said, therefore, to have the virtues of a formally realizable doctrine. It may be unconcerned with the operational effects of federal legislation on effective local governmental service provision in a particular case, but if we are thinking about how to provide meaningful protection for local power, we cannot investigate operational impacts each time. Perhaps we are better off simply articulating some clear lines of demarcation, easily applied, and leaving it at that.

There are reasons to be skeptical of this defense of the Court's approach. If the federal statutes invalidated by the recent cases actually were redistributing or facilitating local power rather than simply limiting it, then an approach to central-local relations that prohibits such redistribution or facilitation may do affirmative harm to the values associated with the defense of local autonomy. In other words, the problem is not just that the doctrine covers some cases in which federal power is not a threat to local autonomy. The problem is that the doctrine entrenches existing limitations on local autonomy in the name of protecting it. And it does so needlessly.

It is not obvious that it makes sense to establish an anticommandeering rule at the level of generality at which it is now pitched. As a general matter, a prohibition against commandeering might be thought to preserve the kind of localist interest that underlay National League of Cities. Federal commands to carry out national functions such as federal park maintenance, for example, would not appear to 
vindicate any easily identifiable, offsetting localist interest. But consider a rule that distinguished between, on the one hand, cases in which the federal command protected some jurisdictions from the harms imposed by neighbors, and, on the other, cases in which the command simply foisted federal responsibilities onto local actors. Under such a rule, the federal government could not command states or localities to maintain federally owned lands, though it could command them to take responsibility for the extralocal costs that they impose on neighbors. That rule might itself unduly privilege the importance of formal legal title, but it would not require one to identify traditionally local governmental functions. Nor would it require one to weigh the interest in local autonomy against the competing compelling national interest. Such a rule would not seem to be unworkable, therefore, in the way that the National League of Cities' balancing test was unworkable. ${ }^{178}$ In instances where competing localist interests are affected by central intervention, it is not clear which localist interest should predominate. Precisely because such judgments are indeterminate, however, it is problematic to adopt a rule that resolves all of them by limiting the federal government's power to alter the current distribution of local autonomy, as the Court recently has done. An anticommandeering rule limited to circumstances in which no competing localist interests were present would vindicate the interest in localism without threatening it at the same time.

One might object that there is always some localist interest that can be offered on behalf of federal intervention, and thus there is no limit under such a view to the scope of central power. Of course, if such localist arguments have force, then it is hard to see how localism would support a legal regime that per se rejects such localist defenses of federal intervention. If the objection is rooted instead in a suspicion that many localist arguments are really pretextual, then one is really contending only that some localist arguments are better than others and that it is important to distinguish the strong localist arguments from the weak ones. Our understanding of why it is worth pro-

178. It would require one to distinguish between the two kinds of central intervention identified at the outset. There will no doubt be cases at the margin, but so, too, are there cases at the margin under the current doctrine. See TRIBE, supra note 109, at 893 (noting problems with the workability of the supposedly bright-line rule that the Court fashioned in Printz v. United States, 521 U.S. 98 (1997)). What distinguishes commandeering from preemption? What is commercial activity and what is not? Even the most categorical of doctrines is not immune from such classification concerns. 
tecting local autonomy would profit from a legal regime that required us to articulate just such distinctions.

Indeed, once one sees the complicated nature of local autonomy one also might see the problems with allowing the Court in particular to resolve them. The Court might be a particularly poor institution to protect local autonomy precisely because the context of litigation encourages the Court to conceive of the defendant jurisdiction as an island under attack from central power. The litigation context obscures the ways central intervention distributes power across myriad local jurisdictions, altering their relations to one another, and affecting their capacity to respond to a variety of extralocal pressures. No single state is well-suited to represent the often divergent understandings of local autonomy of their neighbors. ${ }^{179}$

The case for reform is somewhat less compelling with respect to the decisions that identify internal limits on Congress's powers. There, too, the Court's current means of drawing lines seems to ignore the ways central power may be facilitating local power even as it preempts some local policymaking discretion. But it may be that there is no more workable manner of enforcing some limitation on federal authority. This observation, however, may only indicate that such internal constraints ultimately serve as a poor means of providing protection for local power, even if there are other reasons for concluding that they are justified-such as, perhaps, limiting the scope of private liability for violent crimes. In fact, an argument along these lines may emanate more from a nationalist judgment about the amount of liability to which individuals should be subject in our constitutional order than from a distinctly localist one. Indeed, one might conclude that a nationalist concern with individual liberty underlies the Court's decision in Morrison and trumps the competing localist concern that the state attorneys general may have pressed. In this re-

179. There are, to be sure, risks in permitting the central legislature to be the protector of local autonomy - it may overreach in the opposite direction. One may expect that in intervening to distribute local autonomy, the central government may impose restrictions that are not necessary to any plausibly localist end. As well, one might contend that if the Court is a problematic arbiter of the content of local autonomy in this context, then it may also be a problematic arbiter in the context of state-local legal relations, thereby calling into question the propriety of decision like Mt. Laurel. But it should be noted that the Mt. Laurel Court issued its decision with a clear grasp that far more was at stake in that case than a simple clash between the autonomy of a single, island jurisdiction and the central government. At stake instead, the court realized, was the background rule structure which constrains, and empowers, local governments generally in New Jersey. It is that larger perspective on central-local relations that the United States Supreme Court's recent federalism decisions consistently eschew. 
gard, Morrison promotes an independent national interest more than a localist one. Even if the decision is correct, in other words, it is not at all clear that it is correct because it protects local autonomy.

That arguments on behalf of local autonomy may be made in defense of central lawmaking does not mean that only localist arguments may be used in defense of central power. There are reasons, as noted above, for exercising national power even when it will trump local autonomy. But it is important to distinguish the cases in which the argument for national power rests on distinctly nationalist claims from the cases in which it rests on localist claims. The distinction is important because the traditional reasons for preferring centralized decisionmaking over local decisionmaking may not seem sufficiently strong in some cases. In those cases, it should be recognized that the centralized decision may promote the very values that warrant respect for local autonomy. For this reason, a legal regime that would permit the federal government to exercise power more freely than the current decisions permit cannot easily be described as centralist.

\section{CONCLUSION}

The discussion of the federalism revival should be seen as part of a broader, and more deeply rooted, but also clearly contestable, way of thinking about how central governments can protect local power. The way of thinking about localism that the recent federalism revival reflects should be troubling even to those who find themselves attracted by the recent tilt towards localism. It should be troubling because of the risk that it will prevent us from thinking creatively about ways central governments can promote local power at the very moment when an affinity for localist values suggests the virtues in doing just that.

There is a growing recognition that the role of central government should not be to supplant local decisionmaking so much as to encourage local jurisdictions to understand their role as components of a larger coordinated system that benefits from cooperative interlocal behavior. At the state level, this recognition has led to proposals for reform in which new state laws operate not simply to limit local discretion because of state-wide concerns but rather to encourage local governments to understand their interconnections with other communities. These proposals-marching under the banner of the new regionalism-suggest that old distinctions between the central and the local may not be helpful. The important ground of inquiry 
concerns how background rules of central law may be adjusted to foster and promote beneficial interlocal cooperation. ${ }^{180}$

At the federal level too, there is an increasing emphasis on deploying central power to promote interconnection among local decisionmakers. Charles Sabel and Michael Dorf have suggested the ways in which national central power can be deployed, and, indeed, must be deployed, to engage local decisionmakers in effective problem solving. ${ }^{181}$ They do not seek to increase the amount of discretion that local jurisdictions now have simply for the sake of empowering local decisionmakers. Rather, they seek to establish central frameworks that will make it possible for the central government to learn about potentially generalizable solutions to pressing problems from local decisionmakers. ${ }^{182}$ Again, these reform proposals emphasize the importance of local discretion while refusing to distinguish sharply between the central and local realms. ${ }^{183}$

In light of these reform proposals, we should not criticize the federalism revival only for its doctrinal excesses. Nor should we feel compelled to romanticize central power (or demonize local power) in order to object to the Court's current localist path. We should instead challenge the now-ascendant vision of what protecting local autonomy demands. Not all arguments for central power are of a similar character. Some seek to vindicate a competing central governmental policy that is thought to be of such importance that it trumps any competing interest in localism. Other arguments for central power, however, should be understood as localist arguments in their own right. Persons attracted to the virtues of local decisionmaking should be suspicious of an emerging legal regime that refuses to attend to such distinctions-even if that legal regime purports to be vindicating localist virtues.

180. See e.g., FRUG, supra note 9, at 85-91 (suggesting that city power and local government could be used to promote community building); Gillette, supra note 9, at 195 (discussing the role that background rules of state law play in frustrating and inducing interlocal bargains).

181. See Dorf \& Sabel, supra note 9, at 316-23 (analyzing the form of democracy resulting from public choices made by means of tiered councils that collaborate with local citizens to organize service provision).

182. Id.

183. Id. 